\title{
Article \\ Activating Transcription Factor 3 Protects against Restraint Stress-Induced Gastrointestinal Injury in Mice
}

\author{
Dun-Jie Chuang ${ }^{1}$, Subhashree Pethaperumal ${ }^{1}$, Bijaya Siwakoti ${ }^{1}$, Hung-Jen Chien ${ }^{2}$, Ching-Feng Cheng ${ }^{3,4}(\mathbb{D}$, \\ Shih-Che Hung ${ }^{5}$, Te-Sheng Lien ${ }^{1}$, Der-Shan Sun ${ }^{1,5}$ and Hsin-Hou Chang $1,5, *$ (D) \\ 1 Department of Molecular Biology and Human Genetics, Tzu-Chi University, Hualien 970, Taiwan; \\ 104727107@gms.tcu.edu.tw (D.-J.C.); subhashreepethaperumal@gmail.com (S.P.); \\ bijaya2580@gmail.com (B.S.); alan211@mail.tcu.edu.tw (T.-S.L.); dssun@mail.tcu.edu.tw (D.-S.S.) \\ 2 Institute of Biotechnology, National Tsing Hua University, Hsinchu 300, Taiwan; chienhj1026@gmail.com \\ 3 Department of Pediatrics, Taipei Tzu Chi Hospital, Buddhist Tzu Chi Medical Foundation, \\ New Taipei City 231, Taiwan; chengcf@mail.tcu.edu.tw \\ 4 Institute of Biomedical Sciences, Academia Sinica, Taipei 115, Taiwan \\ 5 Institute of Medical Sciences, Tzu-Chi University, Hualien 970, Taiwan; 102353113@gms.tcu.edu.tw \\ * Correspondence: hhchang@mail.tcu.edu.tw; Tel.: +886-3-8565301 (ext. 2667)
}

check for updates

Citation: Chuang, D.-J.;

Pethaperumal, S.; Siwakoti, B.; Chien,

H.-J.; Cheng, C.-F.; Hung, S.-C.; Lien,

T.-S.; Sun, D.-S.; Chang, H.-H.

Activating Transcription Factor 3

Protects against Restraint Stress

-Induced Gastrointestinal Injury in

Mice. Cells 2021, 10, 3530. https://

doi.org/10.3390/cells10123530

Academic Editor: Marc Basson

Received: 6 November 2021

Accepted: 11 December 2021

Published: 14 December 2021

Publisher's Note: MDPI stays neutral with regard to jurisdictional claims in published maps and institutional affiliations.

Copyright: (c) 2021 by the authors. Licensee MDPI, Basel, Switzerland. This article is an open access article distributed under the terms and conditions of the Creative Commons Attribution (CC BY) license (https:/ / creativecommons.org/licenses/by/ $4.0 /)$.

\begin{abstract}
Psychological stress increases the risk of gastrointestinal (GI) tract diseases, which involve bidirectional communication of the GI and nerves systems. Acute stress leads to GI ulcers; however, the mechanism of the native cellular protection pathway, which safeguards tissue integrality and maintains GI homeostasis, remains to be investigated. In a mouse model of this study, restraint stress induced GI leakage, abnormal tight junction protein expression, and cell death of gut epithelial cells. The expression of activating transcription factor 3 (ATF3), a stress-responsive transcription factor, is upregulated in the GI tissues of stressed animals. ATF3-deficient mice displayed an exacerbated phenotype of GI injuries. These results suggested that, in response to stress, ATF3 is part of the native cellular protective pathway in the GI system, which could be a molecular target for managing psychological stress-induced GI tract diseases.
\end{abstract}

Keywords: ATF3; gastrointestinal tract; intestinal leakage; tight junction; cell death; gut epithelial cell; stress ulcer

\section{Introduction}

Psychological stress can increase the risk of gastrointestinal (GI) tract diseases [1-3]. Major mental disorders [4], such as depression and anxiety [2], bipolar disorder [5], schizophrenia [6], dementia [7,8], and autism [9], are all associated with an increased risk of GI tract diseases. Such a high correlation between psychological stress and GI tract disorders may be explained through bidirectional communication of the gut-brain axis that is composed of the central nervous system (CNS) and neuroendocrine, immune, and GI systems [10,11]. GI tract defects may increase the risk of and exacerbate CNS disorders [7,8]. These GI tract disorders are developed chronically; however, the short-term impact of psychological stress on the development of GI tract disorders remains elusive. Additionally, from a therapeutic point of view, methods of diagnosing and detecting early GI tract disorders are required.

Activating transcription factor 3 (ATF3), a member of the mammalian activation transcription factor/cAMP responsive element-binding protein family, is a stress-induced transcription factor critical in modulating metabolism, immunity, and oncogenesis [12]. Several pieces of evidence have indicated that ATF3 plays a critical role in regulating the homeostasis of the GI system. For example, ATF3 is critical in maintaining mucosal immunity [13] and healthy immune-microbiota interactions [14]. ATF3 also ameliorates colitis [15] and facilitates intestinal regeneration [16]. This evidence collectively suggests that ATF3 plays a crucial role in the maintenance of normal intestinal function. However, the role of ATF3 in acute psychological stress-induced GI injuries remains elusive. 
Examining restraint stress is a commonly used method to investigate acute or chronic psychological stress-related behavioral, biochemical, and physiological changes in laboratory animals [17-19]. After experiencing restraint and immobilization stress, animals displayed higher levels of anxiety [17]. Chronic restraint stress stimulations that last for weeks can lead to brain abnormalities [20-22], intestinal dysfunction [23], and dysbiosis [24-26] in experimental animals. Since the gut-brain axis is a bidirectional regulation system between the CNS and GI tract [27], restraint stress can affect both sides of the gut-brain axis, and using the restraint stress model is a feasible means for the development of methods of early diagnosis and detection of stress-induced GI disorders. However, measurement methods of gut leakage in the currently available animal models present several disadvantages. For example, the methods may be time-consuming (e.g., the lactulose/mannitol test requires two orally administered nonmetabolized sugars over a 6-h period) or require specific equipment (e.g., high-pressure liquid chromatography or liquid chromatography combined with mass spectrometry) or isotope labeling (e.g., ${ }^{51}$ Cr-ethylenediaminetetraacetic acid) [28]. Endoscopy examination is useful on the evaluation and management of duodenal ulcer in clinical settings $[29,30]$. However, because mice are too small, such technique is not feasible in this model, despite how we still see some hemorrhage lesions in the GI tract of stressed mice (Figure S1A). As a result, to observe timely results of gut leakage in the experimental animal, an easier method is desired.

We developed a simple method to analyze stress-induced GI leakage. Using intestinal, nonabsorbable, Evans blue dye, we observed the timely changes of mouse intestinal leakage. We used a combination of analysis methods, namely flow cytometry, quantitative reverse transcription polymerase chain reaction (qRT-PCR), and immunohistochemistry (IHC) staining analyses, to analyze the cellular and molecular changes in the early phase of the injury. Restraint stress induced an ulcer-like injury in mice, and proton pump inhibitor (PPI) treatments rescued the gut leakage. Additionally, an ATF3 deficiency exacerbated the leakage in mice, suggesting that ATF3 plays a protective role in stress ulcers.

\section{Materials and Methods}

\subsection{Laboratory Mice}

Wild-type (WT) C57BL/6J mice aged 8-12 weeks were purchased from the National Laboratory Animal Center (Taipei, Taiwan) [31-36]. Genetically deficient ATF3-/- (ATF3 KO) mice with a C57BL/6J background [37,38] were provided by Dr. Tsonwin Hai. ATF3 $^{-/-}$mice were backcrossed with WT C57Bl/6J mice over six generations. All animals were housed in the Animal Center of Tzu-Chi University in a specific pathogen-free temperature- and light-controlled environment with free access to filtered water and food. Approximately 300 wild-type mice and $80 \mathrm{ATF}^{-/-}$mice were employed in this study. All experimental protocols for examining the experimental animals were approved by the Animal Care and Use Committee of Tzu-Chi University, Hualien, Taiwan (approval ID: 110024).

\subsection{Measurement of Stress-Induced GI Leakage}

To induce restraint stress $[39,40]$, the mice were kept in a 50-mL plastic falcon tube for $9 \mathrm{~h}$. Holes were created at the tapering end of the falcon tube to ensure sufficient air supply. Blood samples $(50 \mu \mathrm{L})$ were collected four times during the experiment at $0,5,7$, and $9 \mathrm{~h}$ after the stress challenge began. Evans blue $(1.2 \mathrm{~g} / \mathrm{kg}$, Santa Cruz Biotechnology, Santa Cruz, CA, USA) was fed to the mice using a steel feeding tube $4 \mathrm{~h}$ after the commencement of stress challenge. Their blood plasma was isolated by collecting blood in an Eppendorf tube and mixing it with an equal proportion of anticoagulant citrate dextrose solution to prevent coagulation [41-43]. The collected plasma was transferred to 96-well plates, in which the concentration of Evans blue was determined using a full-spectrum analyzer (Multiskan Spectrum, Thermo Fisher Scientific, Waltham, MA, USA) at $620 \mathrm{~nm}$. 


\section{3. qRT-PCR Analysis}

\subsubsection{RNA Isolation and cDNA Preparation}

After $9 \mathrm{~h}$ of stress, a duodenum sample $(1 \mathrm{~cm}$; begins immediately after the pyloric portion of the stomach) from the mice was isolated, washed (phosphate-buffered saline, PBS) and dissolved in Trizol (Ambion, Thermo Fisher Scientific) reagent. After the implementation of the ribonuclease-free deoxyribonuclease treatments and standard isolation protocols, the RNA concentration was analyzed using a NanoDrop spectrophotometer (Thermo Fisher Scientific). The RNA (1 $\mu \mathrm{g})$ was used to synthesize complementary DNA (cDNA) using an iScript cDNA Synthesis Kit (Bio-Rad Laboratories, Hercules, CA, USA). The obtained cDNA was used for PCR and qRT-PCR analysis, and the samples were stored at $-20{ }^{\circ} \mathrm{C}$ before use.

\subsection{2. qRT-PCR}

We used qRT-PCR to analyze the expression of tight junction genes, such as zonula occludens-1 (ZO-1), claudin 3 (CLDN3), and junctional adhesion molecule 3 (JAM3), molecules involve in the maintenance of mucosal homeostasis and intestinal integrality [44-47], in the stomach, duodenum, and jejunum, respectively. cDNA $(2 \mu \mathrm{L})$ was mixed with $10-\mu \mathrm{L}$ SYBR Green (Thermo Fisher Scientific), $0.5 \mu \mathrm{L}$ each of forward and reverse primers, and $7-\mu \mathrm{L} d \mathrm{ddH}_{2} \mathrm{O}$ and quantified in a real-time reverse transcription linkage instrument (StepOnePlus Real-Time PCR System, Thermo Fisher Scientific) with varying annealing temperatures according to the primers. Each sample was run in triplicate, and the average cycle threshold $(\mathrm{Ct})$ values were used to calculate $2^{-\Delta \Delta \mathrm{CT}}$ with that of the internal control-GAPDH (glyceraldehyde-3-phosphate dehydrogenase) gene expression.

\subsection{Flow Cytometry Analysis}

After $9 \mathrm{~h}$ of stress, the duodenum samples $(6 \mathrm{~cm}$, begins immediately after the pyloric portion of the stomach; PBS-washed) were cut into tiny pieces and incubated with a collagenase D (Sigma-Aldrich, Burlington, MA, USA; $1 \mathrm{mg} / \mathrm{mL}$ )-containing serum-free cell culture medium for $30 \mathrm{~min}$ in a $15-\mathrm{mL}$ falcon tube at $37^{\circ} \mathrm{C}$ with shaking (upright shaking incubator; OSI 500, Kansin Instruments, New Taipei City, Taiwan). After the removal of the media by centrifugation, mouse GI epithelial cells were dissociated from the remaining cell and tissue pellets by incubation with $2 \mathrm{~mL}$ of nonenzymatic cell dissociation solution (Sigma-Aldrich) for $10 \mathrm{~min}$ at room temperature. After being washed, each sample of the dissociated cells was fixed with $500 \mu \mathrm{L}$ of a fixation buffer (Cytofix, BD Biosciences, San Jose, CA, USA), mixed properly, and incubated at room temperature for $20 \mathrm{~min}$. These samples were then centrifuged at $300 \times g$ for $5 \mathrm{~min}$. After washing (Perm/Wash buffer, BD Biosciences) and blocking ( $5 \%$ bovine serum albumin in RPMI), the cells were subjected to the staining of CD326 (a gut epithelial cell marker $[48,49]$ ), tight junction, and cell death marker (anti-CD326 epithelial cell marker antibody, BioLegend; anti-occludin antibody and anti-claudin-3 antibody, Thermo Fisher Scientific; anti-cleaved caspase-3 antibody, Cell Signaling Technology, Danvers, MA, USA; propidium iodide (PI), Thermo Fisher Scientific; and annexin $V$, Thermo Fisher Scientific). The samples were then analyzed through flow cytometry (Gallios, Beckman Coulter Life Sciences, Brea, CA, USA) for the quantitative analysis [50-52].

\subsection{Immunohistochemistry (IHC) Tissue Section Preparation}

After $9 \mathrm{~h}$ of stress, the duodenum samples $(6 \mathrm{~cm}$; begins immediately after the pyloric portion of the stomach, PBS-washed) were collected and rinsed with $1 \mathrm{~mL}$ of ice-cold PBS 3 times and Bouin's reagent $\left(1 \mathrm{~mL}, 50 \% \mathrm{ddH}_{2} \mathrm{O}, 45 \%\right.$ absolute ethanol, and $5 \%$ acetic acid) 2 times through the opening of the duodenum. The duodenum was then cut open longitudinally using a surgical blade and washed an additional 2 times with PBS. It was then bisected along its length and Swiss-rolled with a toothpick [53]. Once the entire length of the intestine had been rolled, a pair of forceps was used to remove the rolled tissue from the toothpick, and the tissue was kept in a tissue-embedding cassette in 10\% 
buffered formalin for more than $30 \mathrm{~min}$ for fixation. The rolled tissue was then placed in the organic solvents overnight for dehydration. The dehydrated tissue was then placed in a metal cassette and filled with hot wax. It was cooled until the wax solidified, and the metal cassette was removed. Following the standard protocols of paraffin embedding, removal, antigen retrieval, washes (TBS buffer), and protein blocking (5\% BSA) were conducted $[33,54]$, and the sectioned tissues were subjected to immunofluorescent staining.

\subsection{Immunofluorescent Staining}

Following the previously described methods [33,54], the tissue sections were treated with antibodies diluted with 1\% BSA prepared in a TBS buffer. An anti-occludin antibody (Thermo Fisher Scientific), anti-claudin-3 antibody (Thermo Fisher Scientific), anti-cleaved caspase-3 antibody (Cell Signaling Technology), and 4',6-diamidino-2-phenylindole (DAPI; Sigma-Aldrich) were used for staining. After staining, cover slips were mounted with 30- $\mu \mathrm{L}$ mowiol 4-88 mounting solution (2.5\% 1,4-diazabicyclo-octane, 10\% Mowiol 4-88, $25 \%$ glycerol, and 0.1-M Tris- $\mathrm{HCl}$ ).

\subsection{Imaging of Confocal Microscopy}

Fluorescence imaging was conducted with confocal microscopes (LSM 800, ZEN 2.1 software, Carl Zeiss, Jena, Germany). The Zeiss confocal microscope is equipped with Plan-Apochromat $10 \times / 0.45$, Plan-Apochromat $20 \times / 0.8$, and Plan-Apochromat $40 \times / 1.3$ Oil DIC (UV) VIS-IR lenses. The $10 \times$ lens was applied to capture the gross view (under tile scan mode) and then automatically stitched by the software. The $20 \times$ and $40 \times$ lenses were used to capture detailed structures of the specimens. All scanning was performed under the multichannel mode to obtain sequential signals; the illumination power was identical for each slide. The image contrast was also optimized, and a despeckle filter was used. The DAPI-labeled nuclei were excited using a 405-nm laser, and the signals were collected with an SP 470 filter. The green fluorescence-labeled structures were excited using a 488-nm laser, and the fluorescence signal was collected with an SP 545 filter. The red fluorescence-labeled structures were excited using a 543-nm laser, and the signals were collected with an SP 620 filter. An analysis of at least three independent images was conducted in one section, and quantified results of the fluorescence intensity were obtained using ImageJ software (1.52a, National Institutes of Health, Bethesda, MD, USA) [33,42].

\subsection{Statistical Analyses}

The experimental results were analyzed using Microsoft Office Excel 2003 (Redmond, WA, USA) and SPSS 17 (International Business Machines Corporation, Armonk, NY, USA), and the results were reported as mean \pm standard deviation. Statistical significance of the obtained results was examined using a one-way analysis of variance and post hoc Bonferroni-corrected $t$-test; a probability of type 1 error $\alpha=0.05$ was considered the threshold of statistical significance. Following a key principle governing the ethical use of animals in research that no animal life is wasted, the number of animals used in each experiment must be the minimum necessary to obtain valid and meaningful results $[55,56]$, so we set the level of significance/alpha/type I error of our experiment data at 5\% (0.05) and the power/beta/type II error at 80\% [55] to test our hypothesis. Software G*Power 3.1.9.2 was employed to calculate the mouse sample size needed [57,58]. For example, to compare the mean difference of the plasma Evans blue levels between the 2 groups (WT no stress and WT stress) using $G^{*}$ Power, we determined the effect size as 2.25. If we further set $\alpha$ as 0.05 and the power $(1-\beta)$ as 0.80 , in a two-sided test, we then obtained an estimated total sample size of 10 in 2 groups (i.e., 5 per group, $n=5$ ). To compare the mean differences of plasma Evans blue levels among the 4 groups (WT no stress, WT stress, ATF3 KO no stress, and ATF3 KO stress), according to the $\mathrm{G}^{*}$ Power analyses, we set an effect size of $1.23, \alpha$ of 0.05 , power $(1-\beta)$ of 0.80 , and a two-sided test, and then, we obtained an estimated total sample size of 12 in 4 groups (i.e., 3 per group, $n=3$ ). Thus, a total of 
3-6 mice per group were considered necessary in this study based on the data analyses of the individual experiments.

\section{Results}

3.1. Restraint Stress-Induced GI Tract Leakage Is Sensitively Revealed through Measurement of Plasma Evans Blue Levels That Leaked from GI after Gavage of Live Mice

In this study, orally administrated Evans blue was markedly increased in the plasma of those live mice under restraint stress but not in the control groups without stress. The experiment outline and plasma Evans blue levels are presented in Figure 1A,B, respectively. An examination of the intestinal tissues revealed that, compared with the control groups, Evans blue was primarily distributed in the small intestine of the stressed mice (Figure 1C,D). This suggests that the small intestine is a leakage site after restraint stress.

A

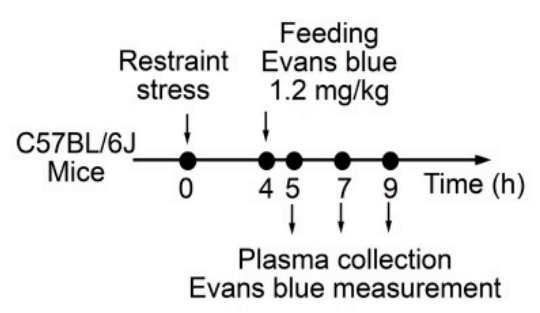

C

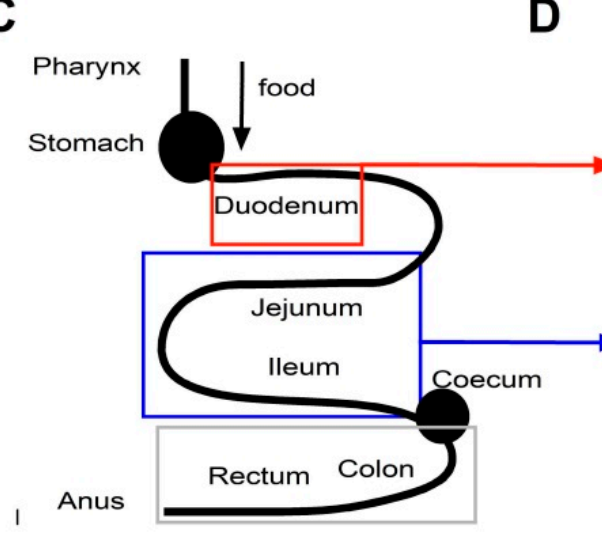

D
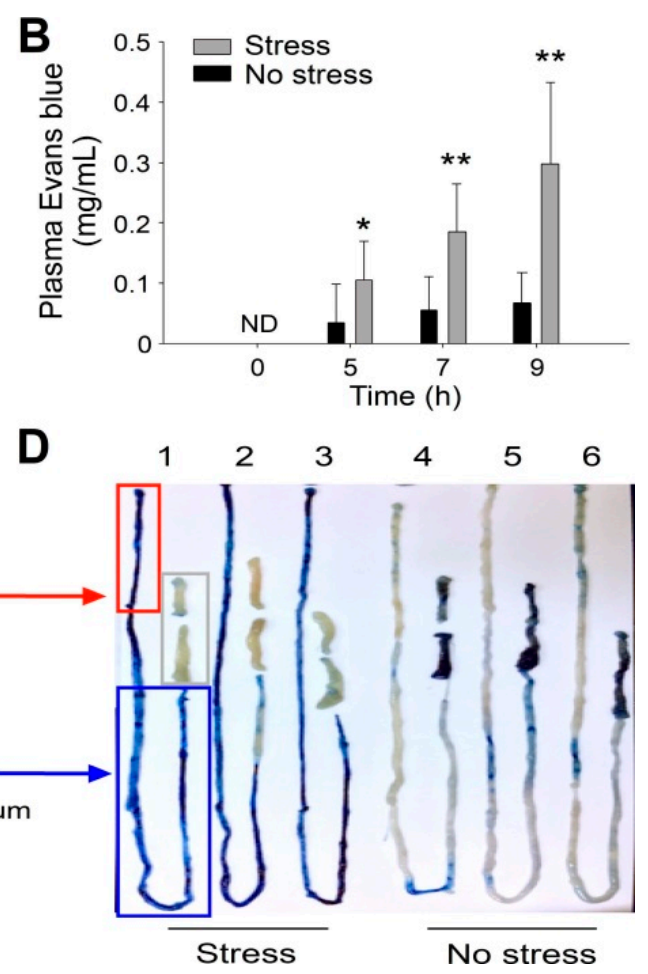

Figure 1. Restraint stress-induced GI leakage is revealed by GI administration of Evans blue. (A) Experiment outline of the restraint stress mouse model with Evans blue treatments. (B) Plasma Evans blue levels of mice with or without restraint stress at 0,5, 7, and $9 \mathrm{~h}$. ND: not detected. Error bars show the standard deviation; ${ }^{*} p<0.05$ and ${ }^{* *} p<0.01$ vs. their respective no stress groups. (C) A schematic diagram of the mouse GI system according to the information provided by previous reports [59,60]. (D) Residue Evans blue in the mouse GI system after the experiment. The residue Evans blue primarily localized in the small intestine (duodenum and jejunum) region in the stressed groups. $n=9$ ( 3 experiments with a total of 9 mice per group).

The expressions of these tight junction genes are highly affected in the duodenum and stomach and less affected in the jejunum (Figure 2; duodenum and stomach with suppression up to a total of three out of three tested tight junction genes; jejunum with one-third). In addition, the mRNA expression levels of the tight junctions appeared more severely affected in the duodenum than in the stomach (Figure 2), suggesting a relatively higher impact of restraint stress in the duodenal region. 

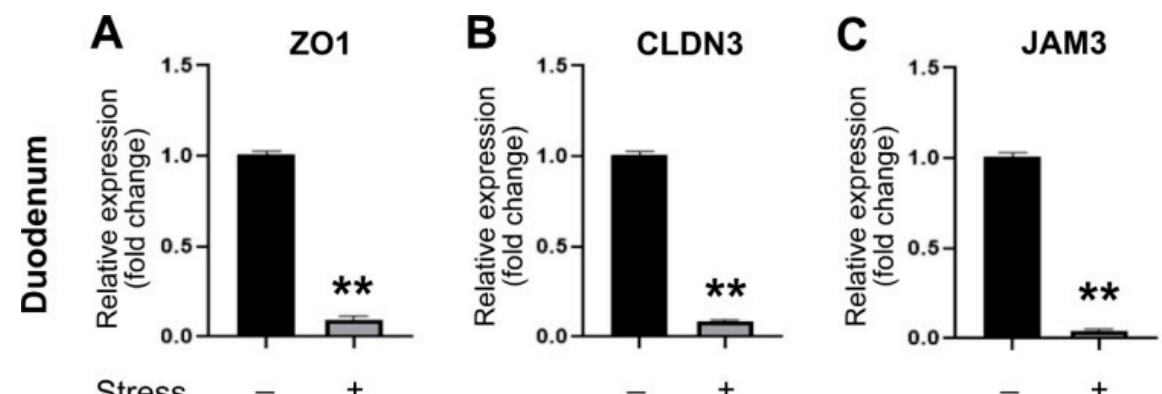

Stress - $\quad+$
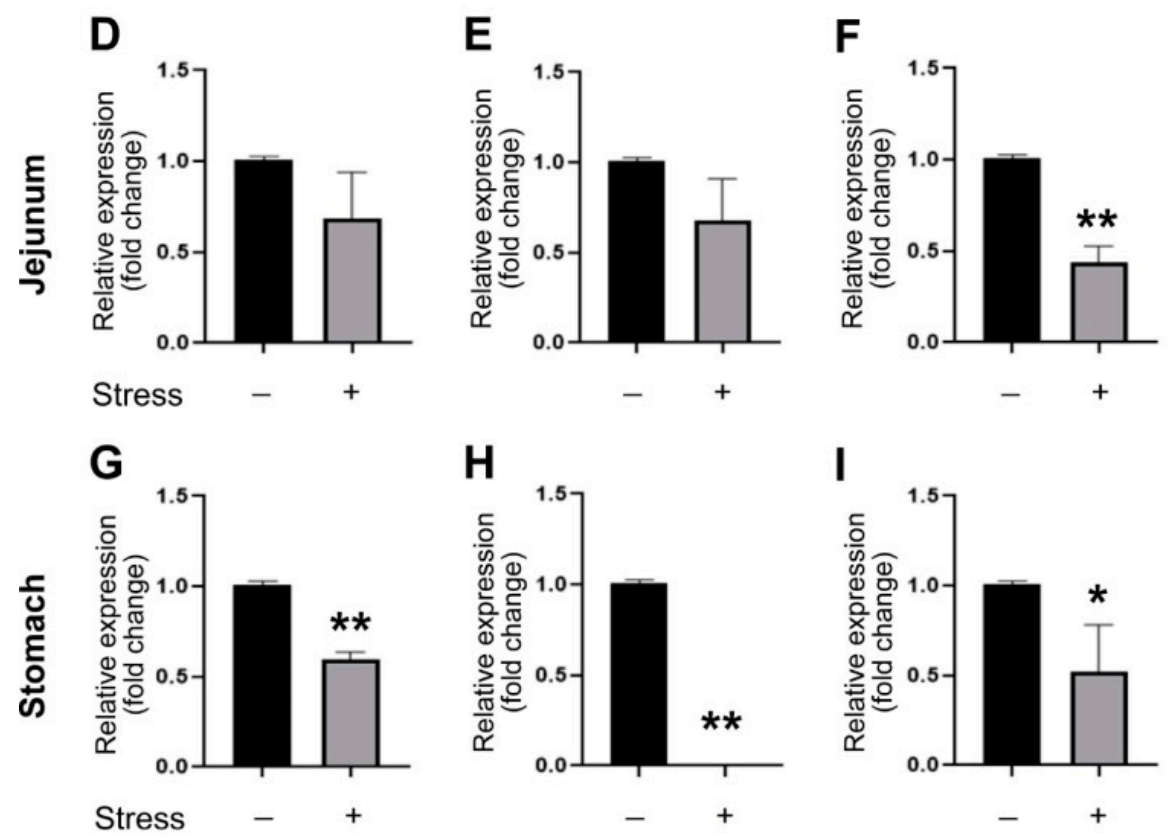

Figure 2. Relative mRNA expression levels of tight junction genes. Through qRT-PCR analysis, the relative mRNA expression levels of tight junction genes ZO-1 (A,D,G), CLDN3 (B,E,H), and JAM3 $(\mathbf{C}, \mathbf{F}, \mathbf{I})$ and of the mouse duodenum $(\mathbf{A}-\mathbf{C})$, jejunum (D-F), and stomach $(\mathbf{G}-\mathbf{I})$ with or without $9 \mathrm{~h}$ of restraint stress. The mRNA expression levels of the control (no stress) groups were normalized to 1 -fold. $n=3$ ( 2 experiments with a total of 3 mice per group). ${ }^{*} p<0.05$ and ${ }^{* *} p<0.01 \mathrm{vs}$. their respective no stress control groups. The "stress - " indicates no stress control groups and the "stress $+"$ indicates the stressed groups.

\subsection{Rescued by PPI Treatments, Restraint Stress-Induced GI Leakage Involves an Ulcer-like Injury}

Duodenal ulcer-like pathophysiology is further supported by the results of the $\mathrm{pH}$ analysis and PPI treatments. Restraint stress markedly induced a more acidic condition in the duodenum than in the jejunum (Figure S1B). This is consistent with the qRT-PCR analyses (Figure 2) that the duodenum is a severely affected region. Additionally, PPI esomeprazole treatments in mice markedly ameliorated the restraint stress-induced gut leakage (Figure 3). These results suggested that a duodenal ulcer-like injury is involved in the restraint stress-induced GI tract leakage.

\subsection{ATF3 Deficiency Exacerbated Stress-Induced Gut Leakage and Disrupted mRNA of Tight Junction Protein ZO-1, CLDN3, and JAM3 Expression in Mouse Duodenum}

Since the duodenum is highly affected by stress, we used duodenal tissue as a putative injury tissue to perform subsequent experiments. The analysis results of qRT-PCR further revealed that the messenger RNA (mRNA) of ATF3 is upregulated by restraint stress in the duodenal tissue (Figure 4). Since ATF3 is a stress response regulator, it plays a protective role in various diseases; ATF3 gene knockout (ATF3 $\left.3^{-/--/-} \mathrm{KO}\right)$ mice were compared to the WT mice to examine the role of ATF3 in this system. An ATF3 deficiency markedly 
exacerbated restraint stress-induced gut leakage (Figure 5A), indicating a protective role of ATF3 in this system. Analyses of duodenal tissue with qPT-PCR revealed that, compared with the WT mice, the mRNA expression levels of tight junction ZO-1 and JAM3 were largely suppressed in $A T F 3^{-/-}$mice, with and without stress (Figure 6). CLDN3 mRNA was markedly suppressed after stress in the WT and $A T F 3^{-/-}$mice (Figure 6). These results suggest that, under an ATF3-deficient condition (e.g., $A T F 3^{-/-}$mice), the mRNA of the tight junction genes is not properly regulated. The flow cytometry results were consistent with the qPT-PCR data (Figure 6) and further indicated that the tight junction protein CLDN3 tended to be suppressed in the CD326 duodenal epithelial cells in both WT and $\mathrm{ATF3}^{-/-}$mice (Figure 5B-E). Notably, in addition to the reduced CLDN3 levels, the CD326 levels of the duodenal cells also seem reduced in ATF3-deficient mice with an unknown mechanism (Figure $5 \mathrm{~B}$ vs. Figure $5 \mathrm{C}$; reduced CD326 $6^{+}$population in $A T F 3^{-/-}$mice). IHC data also revealed that CLDN3 was markedly suppressed in WT and $A T F 3^{-1-}$ mice after stress (Figure 7). These results collectively suggest that a dysregulated tight junction is involved in stress-induced intestinal changes.
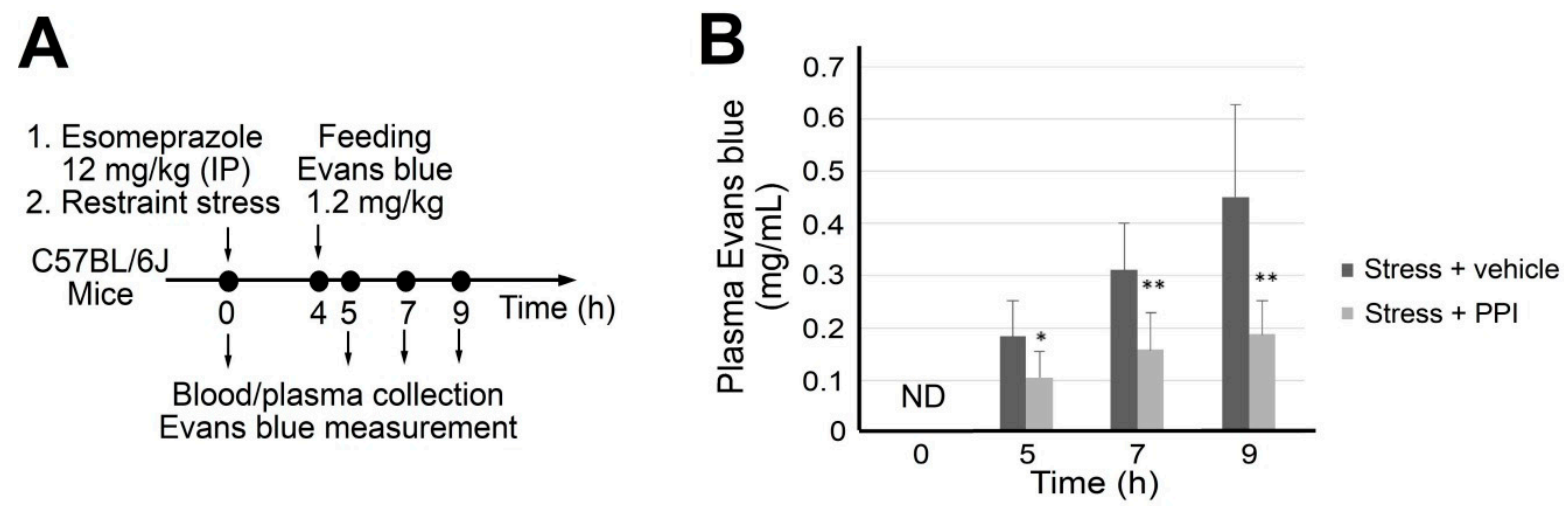

Figure 3. Proton pump inhibitor (PPI) rescues stress-induced GI leakage. (A) Experiment outline of PPI esomeprazole treatments in the restraint stress mouse model. (B) Plasma Evans blue levels of stressed mice with or without esomeprazole treatments at $0,5,7$, and $9 \mathrm{~h}$. Error bars show the standard deviation; ${ }^{*} p<0.05$ and ${ }^{* *} p<0.01$ vs. their respective control groups without esomeprazole treatments. ND: not detected. $n=6$ ( 3 experiments with a total of 6 mice per group).

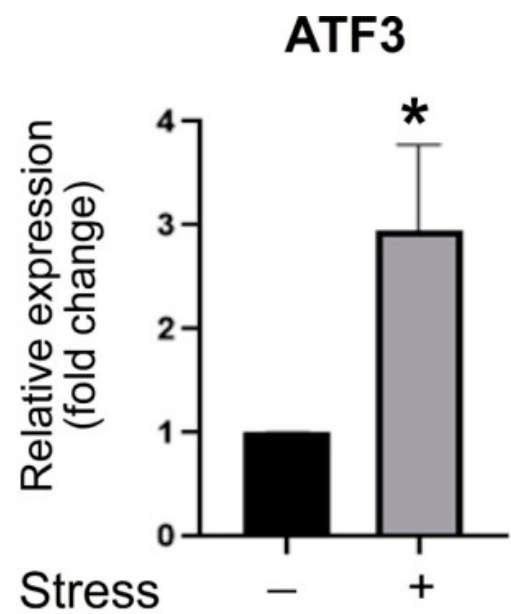

Figure 4. Relative duodenal mRNA expression levels of the ATF3 gene in WT mice. Through qRTPCR analysis, the relative mRNA expression levels of the ATF gene of the mouse duodenum with or without $9 \mathrm{~h}$ of restraint stress. The mRNA expression levels of the control (no stress; stress - ) groups were normalized to 1-fold. Error bars show the standard deviation. $n=3$ ( 2 experiments with a total of 3 mice per group). ${ }^{*} p<0.05$ vs. no stress control groups. The "stress - " indicates no stress control groups and the "stress + " indicates the stressed groups. 
A

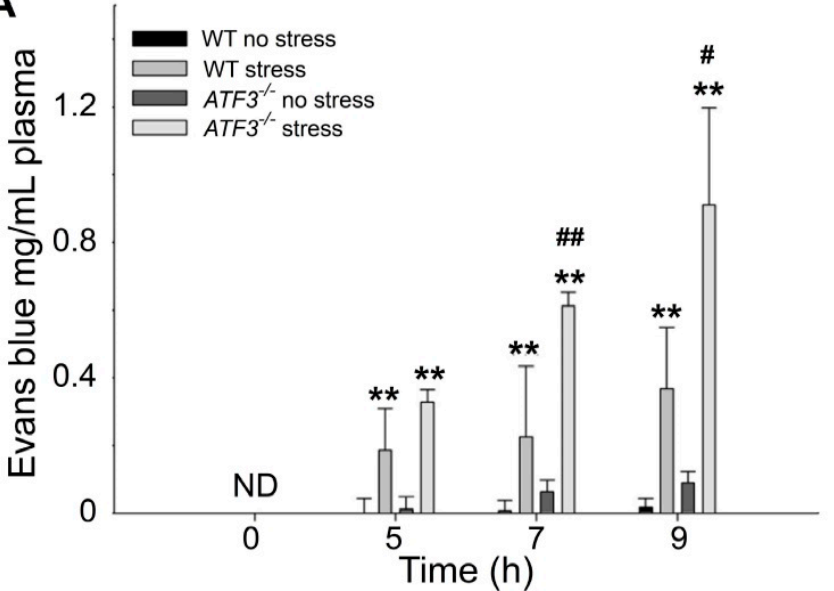

B
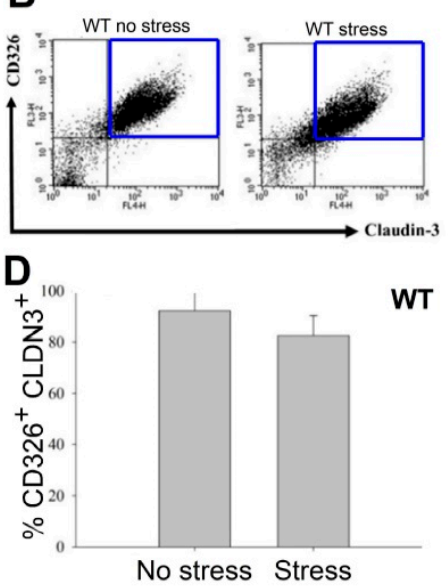

C

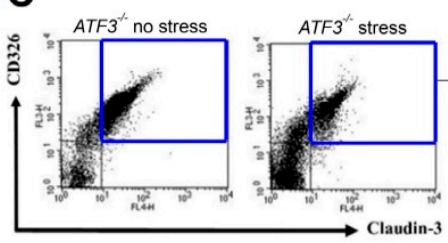

E

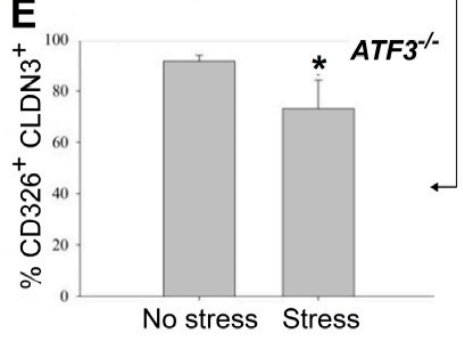

Figure 5. An ATF3 deficiency exacerbates stress-induced GI injuries and claudin 3 (CLDN3) suppression. (A) Plasma Evans blue levels of WT (WT) and ATF3 gene knockout (KO; $A T F 3^{-/-}$) mice with or without stress at $0,5,7$, and $9 \mathrm{~h}$. (B,C) Flow cytometry analysis of tight junction protein CLDN3 expressing gut epithelial (CD326 $6^{+}$CLDN3 $^{+}$double positive) cells in WT (B) and $A T F 3^{-1-}(\mathbf{C})$ mice. (D,E) The quantitative results of flow cytometry CD326 $6^{+} / \mathrm{CLDN3}^{+}$populations in WT (D) and $A T F 3^{-/-}$(E) mice are indicated. (A) \# $p<0.05$ and \#\# $p<0.01$ vs. their respective WT groups and (A-E) * $p<0.05$, ${ }^{* *} p<0.01$ vs. no stress groups; error bars show the standard deviation. (A) $n=6$ ( 3 experiments with a total of 6 mice per group) and (B-E) $n=4$ (2 experiments with a total of 4 mice per group).

A

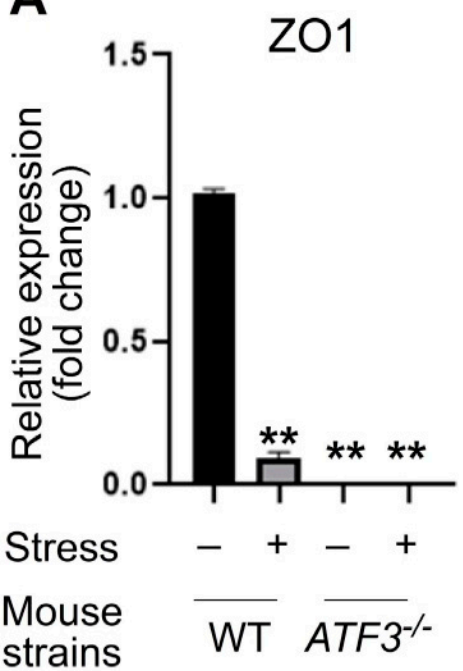

B

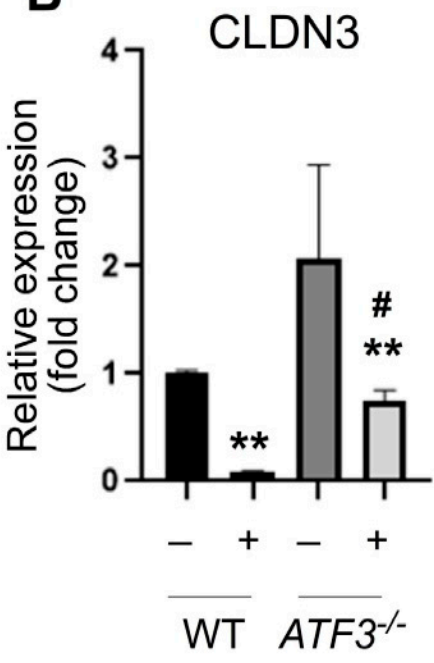

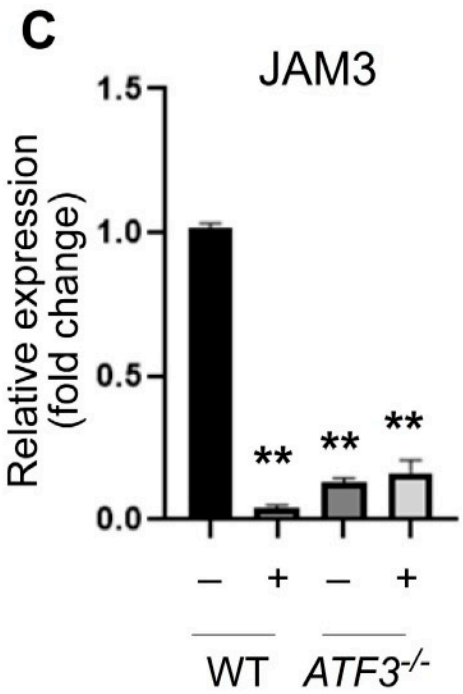

Figure 6. Relative duodenal mRNA expression levels of tight junction genes in WT and $A T F 3^{-/-}$mice. Through a qRT-PCR analysis, the relative mRNA expression levels of tight junction genes ZO-1 (A), CLDN3 (B), and JAM3 (C) of the mouse duodenum with or without $9 \mathrm{~h}$ of restraint stress. The mRNA expression levels of the control (no stress; stress-) groups were normalized to 1-fold. $n=3$ ( 2 experiments with a total of 3 mice per group). Error bars show the standard deviation; ${ }^{* *} p<0.01$ vs. the respective no stress WT control groups and $\# p<0.05$ vs. the respective no stress ATF3 ${ }^{-/}$control groups. The "stress - "indicates no stress control groups and the "stress + " indicates the stressed groups. 
A

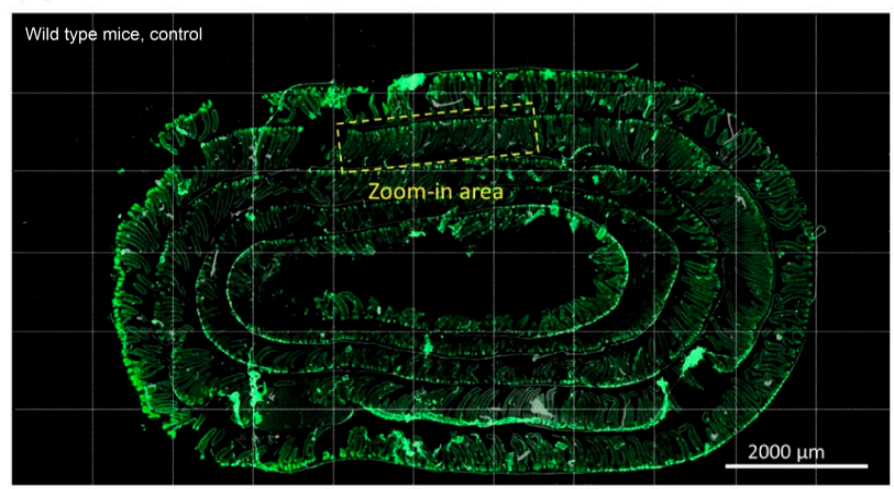

B

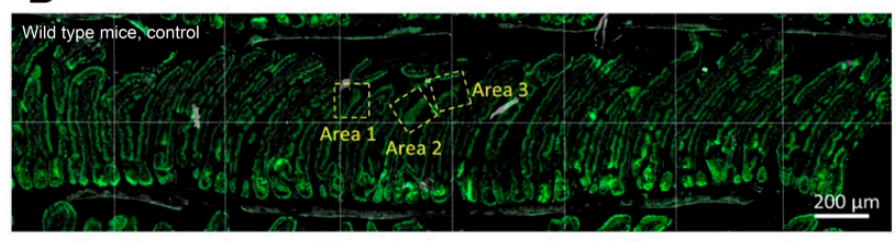

C

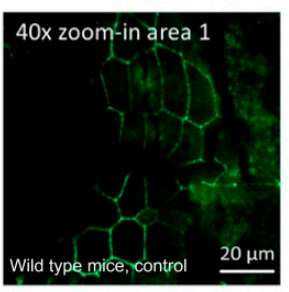

D

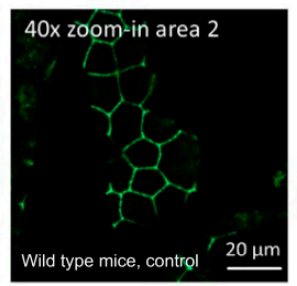

$\mathrm{F}$

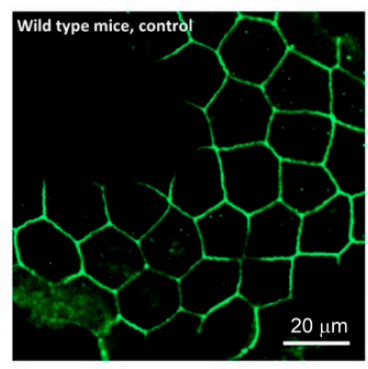

$\mathrm{H}$

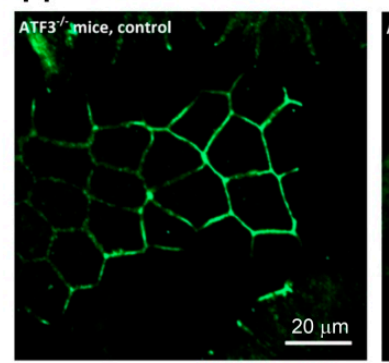

$J$

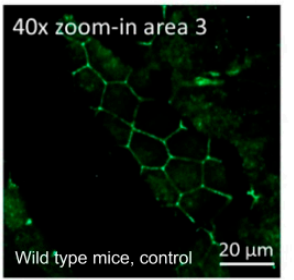

G

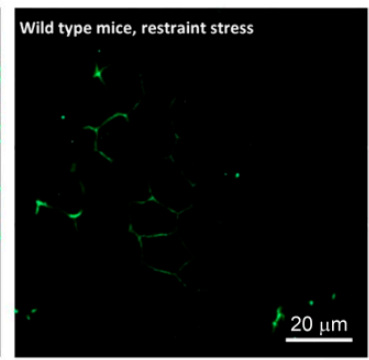

I

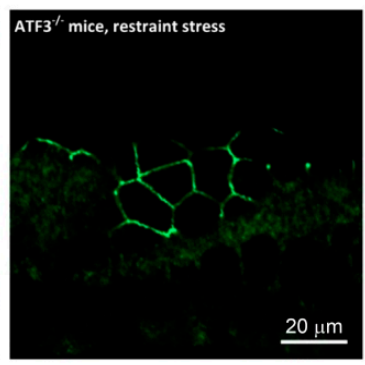

$20 \mu \mathrm{m}$

Figure 7. Confocal microscopy of immunohistochemistry (IHC) CLDN3 staining. Tissue section IHC of a Swiss-rolled duodenal sample was stained with a fluorescence-labeled anti-CLDN3 antibody. (A) A representative image at low magnification is presented. (B) The yellow boxed zoomed-in area in (A) is enlarged as a higher magnification view. (C-E) Areas 1, 2, and 3 in (B) are further enlarged to observe the detailed expression patterns of CLDN3 in the villi of the duodenal tissue. $(\mathbf{F}-\mathbf{I})$ The CLDN3 staining in the WT mice $(\mathbf{F}, \mathbf{G})$ was compared to $A T F 3^{-/}$mutants $(\mathbf{H}, \mathbf{I})$ without $(\mathbf{F}, \mathbf{H})$ or with $(\mathbf{G}, \mathbf{I})$ restraint stress. (J) The quantitative results are obtained from 3 images at various areas; ${ }^{* *} p<0.01$ vs. the respective no stress groups. (J) The averaged mean fluorescence intensity of the WT no stress groups was normalized to 1-fold. (A-G) WT mice and $(\mathbf{H}, \mathbf{I}) \mathrm{ATF}^{-/-}$mutants. Scale bars: $2000 \mu \mathrm{m}(\mathbf{A}), 200 \mu \mathrm{m}(\mathbf{B})$, and $20 \mu \mathrm{m}(\mathbf{C}-\mathbf{I})$. Error bars show the standard deviation.

\subsection{ATF3 Deficiency Exacerbated Stress-Induced Cell Death of Duodenal Epithelial Cells}

Using annexin V, PI, and CD326 triple staining and flow cytometry, we determined that stress induced markedly higher levels of duodenal epithelial cell death $\left(\mathrm{CD} 326^{+} / \mathrm{PI}^{+} /\right.$annexin $\mathrm{V}^{+}$cell population) in both WT and $A T F 3^{-/-}$mice than in the no stress groups (Figure $8 \mathrm{~A}-\mathrm{J}$ ). Consistent with this, the duodenal epithelial cells of the WT and ATF3 ${ }^{-1-}$ mice also displayed considerably higher levels of activated and cleaved-form caspase 3 signals after stress (Figure 8K-P) than the control mice. These results suggest that hours of restraint stress are sufficient to induce the apoptotic cell death of duodenal epithelial cells in mice. Confocal microscopy and IHC analyses were performed to verify this result. Consistently, the IHC data of Swiss-rolled duodenal tissue samples revealed that restraint stress induced activated-form caspase-3-positive intestinal cells specifically in the villi areas (Figure 9). Compared with the control groups, the activated-form caspase-3-positive intestinal cells were markedly increased after stress in the WT and $A T F 3^{-/-}$mice (Figure 10). These results suggest that, in addition to the dysregulation of tight junction proteins, duodenal epithelial cell death is also involved in stress-induced ulcer-like injuries. 
A

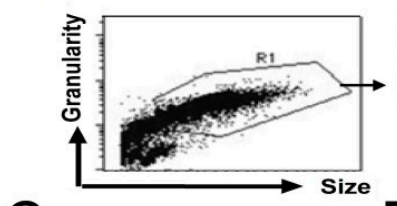

C

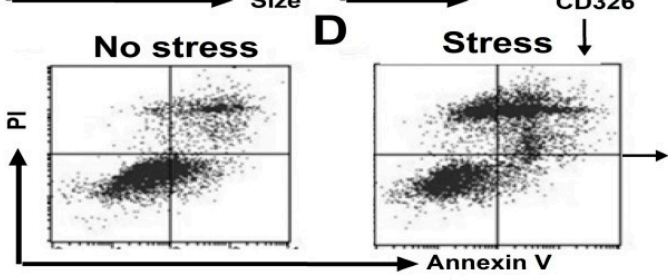

E

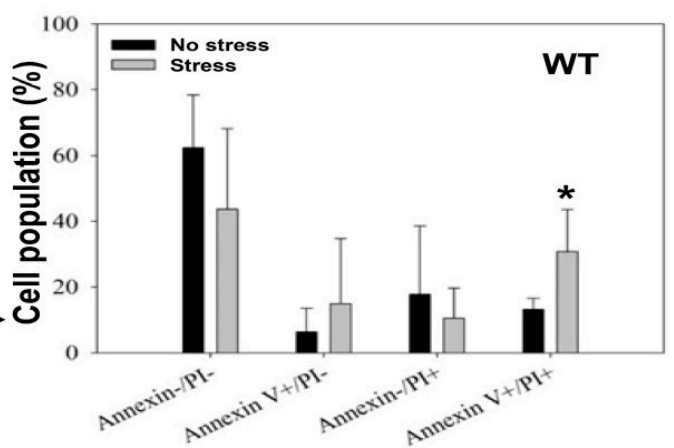

J

F

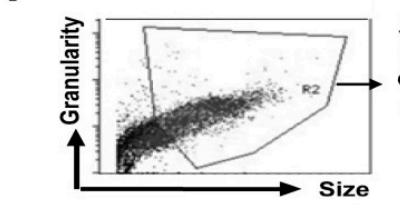

H

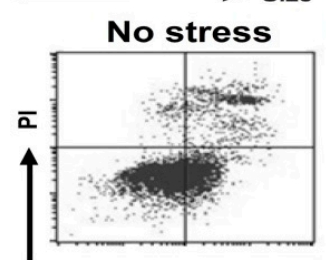

G

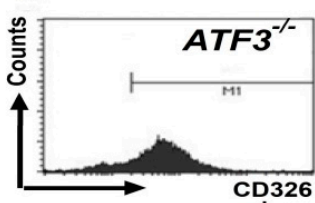

K
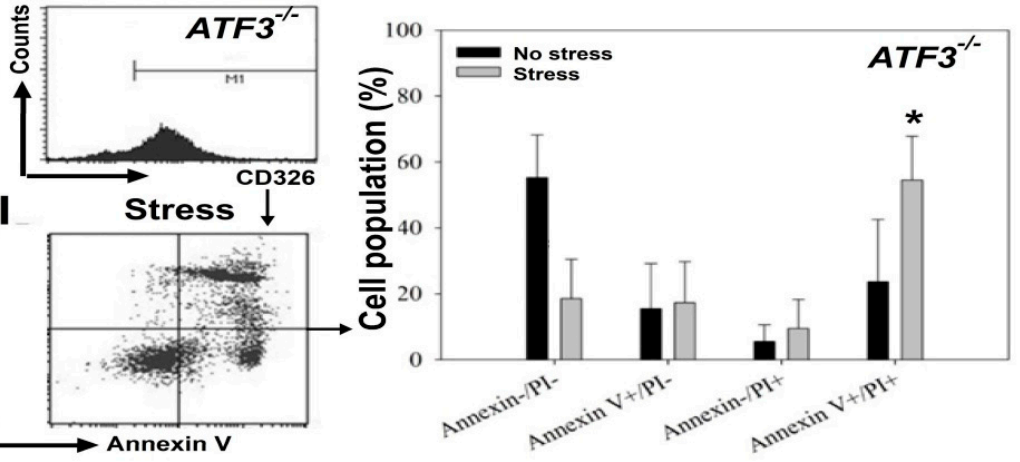

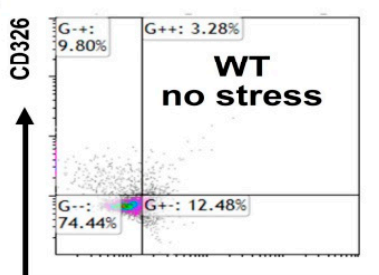

$\mathbf{N}$

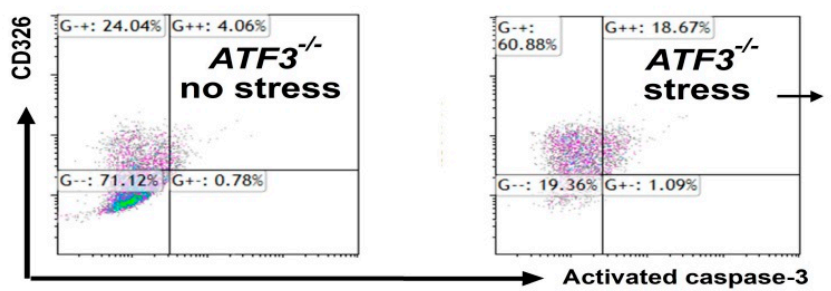

$\mathbf{L}$

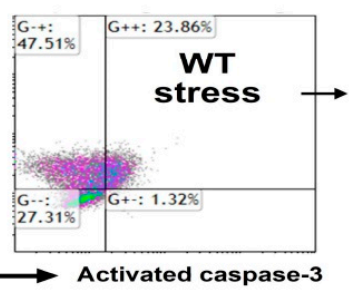

M
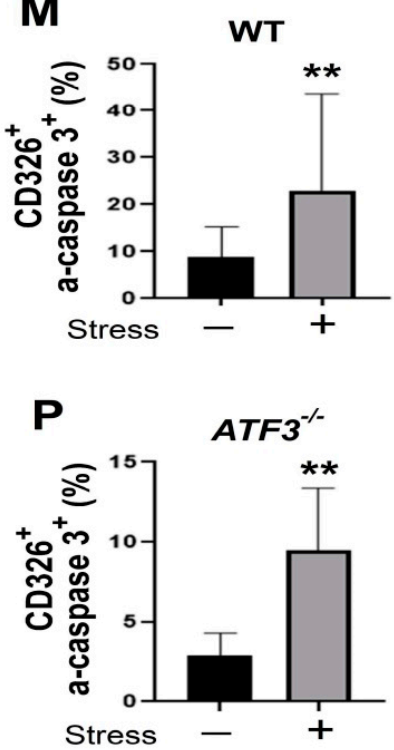

Figure 8. Flow cytometry results of restraint stress-induced GI cell death. (A-E) Analyses of WT mouse samples. The gating $(\mathbf{A}, \mathbf{B})$ and analysis $(\mathbf{C}, \mathbf{D})$ of $\mathrm{CD} 326^{+} / \mathrm{PI}^{+} /$annexin $\mathrm{V}^{+}$dead duodenal epithelial cells from mice without $(\mathbf{C})$ or with (D) restraint stress, and the quantitative results (E) are revealed. (F-J) Analyses of the ATF3 ${ }^{-1-}$ mouse samples. The gating $(\mathbf{F}, \mathbf{G})$ and analysis $(\mathbf{H}, \mathbf{I})$ of $\mathrm{CD} 326^{+} / \mathrm{PI}^{+} /$annexin $\mathrm{V}^{+}$dead duodenal epithelial cells from mice without $(\mathbf{H})$ or with $(\mathbf{I})$ restraint stress, and the quantitative results $(\mathrm{J})$ are indicated. $(\mathbf{K}-\mathbf{P})$ Relative levels of $\mathrm{CD} 326^{+} /$activated-form caspase- $3^{+}$ (a-caspase $3^{+}$) apoptotic epithelial cells in WT $(\mathbf{K}-\mathbf{M})$ and $A T F 3^{-/-}(\mathbf{N}-\mathbf{P})$ mice with or without stress are revealed (gating in $(\mathbf{K}, \mathbf{L}, \mathbf{N}, \mathbf{O}))$. $(\mathbf{M}, \mathbf{P})$ The quantitative results are indicated. $n=5$ ( 2 experiments with a total of 5 mice per group). (E,J,M,P) * $p<0.05$ and ${ }^{* *} p<0.01$ vs. their respective no stress control groups. Error bars show the standard deviation. The "stress - " indicates no stress control groups and the "stress +" indicates the stressed groups. 
A

\section{Full view of mouse duodenum}

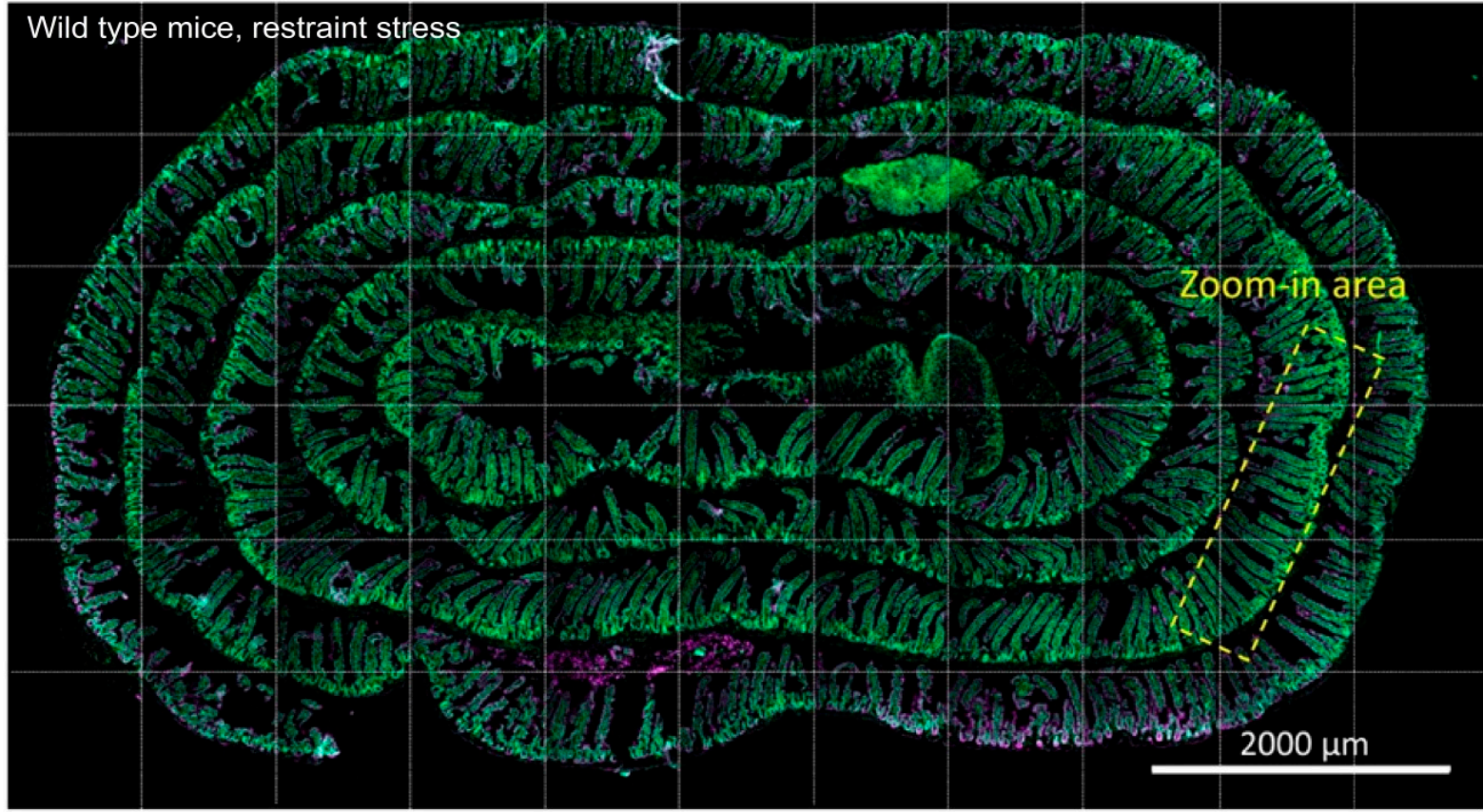

B

20x zoom-in area

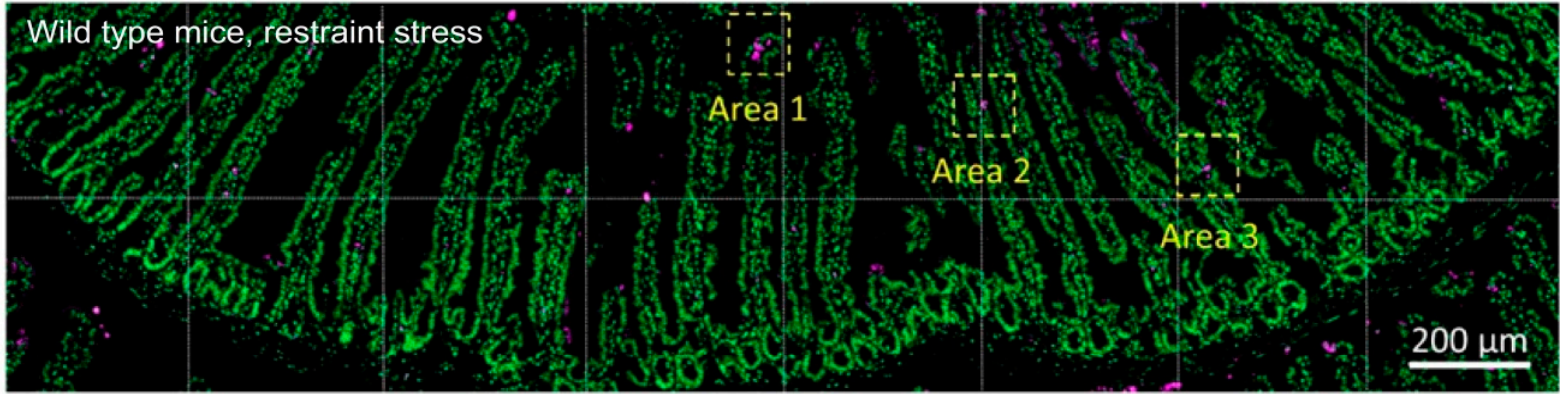

C

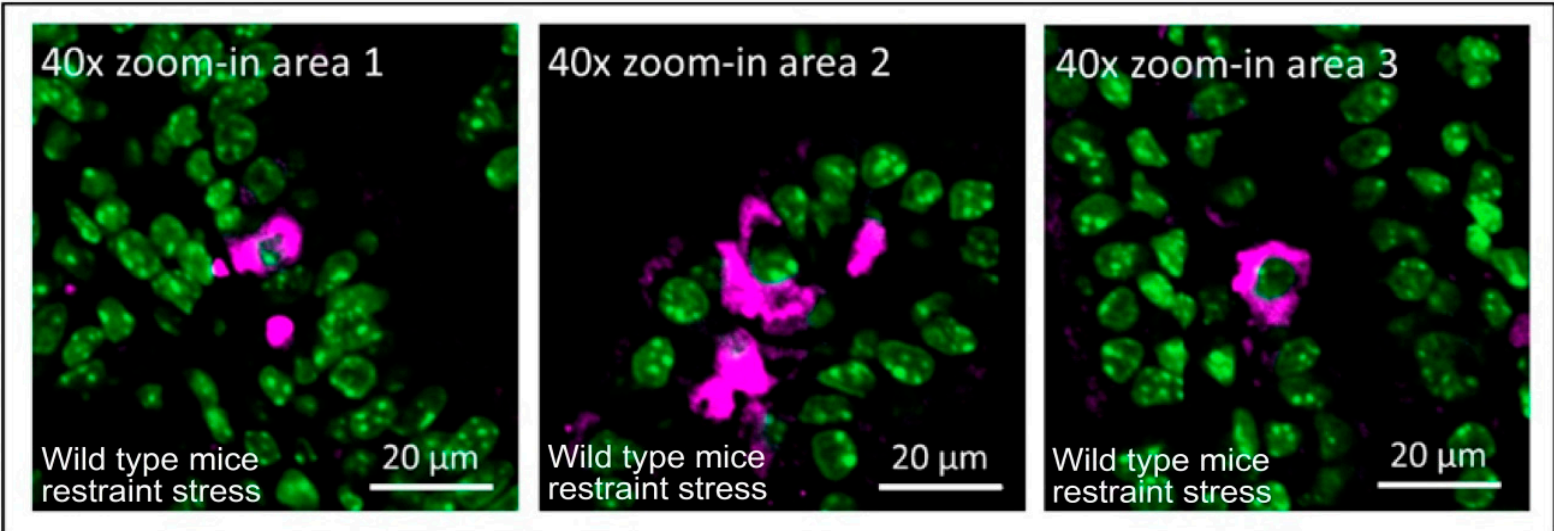

Figure 9. Confocal microscopy of IHC activated-form caspase 3 staining. A tissue section IHC of a Swiss-rolled duodenal sample was stained with a fluorescence-labeled anti-activated-form caspase 3 antibody. (A) A representative image at low magnification is presented. (B) The yellow boxed zoomed-in area in (A) is enlarged as a higher magnification view. (C) Areas 1, 2, and 3 in (B) are further enlarged to observe the detailed expression patterns of activated-form caspase 3 in the villi of duodenal tissue. Scale bars: $2000 \mu \mathrm{m}$ (A), $200 \mu \mathrm{m}$ (B), and $20 \mu \mathrm{m}(\mathbf{C})$. 

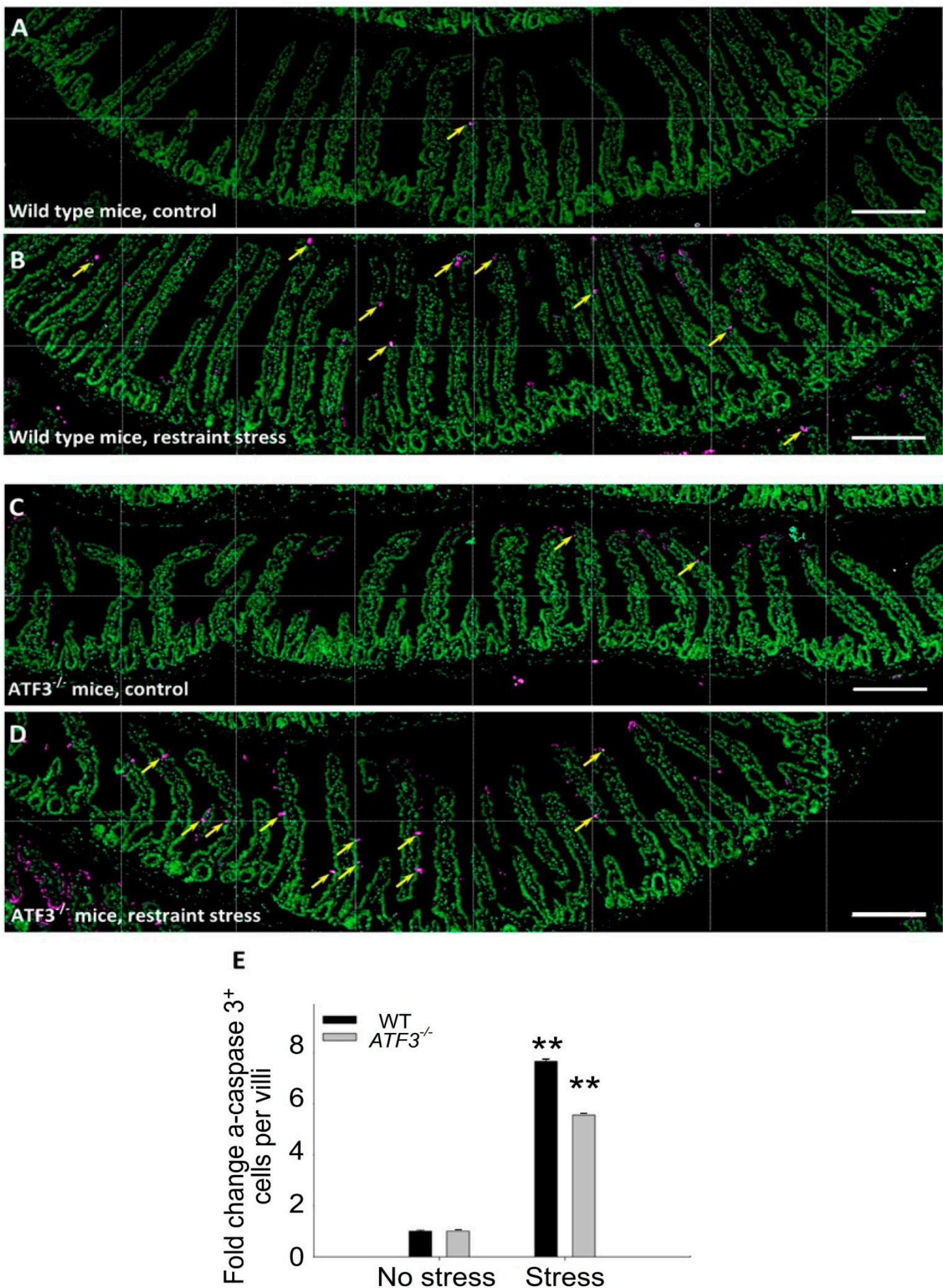

Figure 10. Relative activated-form caspase 3 staining signals in WT and $A T F 3^{-/-}$mice after stress. The WT mice (A,B) was compared to $A T F 3^{-1-}$ mice $(\mathbf{C}, \mathbf{D})$ without $(\mathbf{A}, \mathbf{C})$ and with $(\mathbf{B}, \mathbf{D})$ restraint stress. (E) The quantitative results of activated-form caspase- $3^{+}$(a-caspase $3^{+}$) apoptotic epithelial cells and villi were obtained from three images at various areas. ** $p<0.01$ vs. the respective no stress groups. Scale bars: $200 \mu \mathrm{m}(\mathbf{A}-\mathbf{D})$. Error bars show the standard deviation. 


\section{Discussion}

Peptic ulcer is a disruption of the mucosal surfaces in the inner lining of the GI tract. The primary causes of a peptic ulcer include bacteria Helicobacter pylori, nonsteroidal anti-inflammatory drugs (NSAIDs), tobacco smoking, genetic diseases, and physiological and psychological stresses [61-66]. PPI therapy is a primary treatment for peptic ulcers, but it may cause adverse effects [67]. Compared with the peptic ulcers of other causes, psychological stress-induced peptic ulcers are rarely studied. Evidence has revealed that, independent of $H$. pylori infection or receiving a therapy of NSAIDs, psychological stress markedly increases the risk of peptic ulcers in participants without a prior history of peptic ulcers $[64,68]$. Additionally, in the animal studies, the methods of analyzing GI injuries were primarily available after sacrifice [69-71]. As a result, a favorable live animal model for the treatments of peptic ulcers is required. In this study, we developed the novel orally administered Evans blue live mouse model, which can be repeatedly monitored and analyzed at various time points by measuring the plasma Evans blue levels without sacrificing the animal.

Evans blue dye has a long history of being used as a biological and clinical agent [72]. After intravenous injection, Evans blue, an azo dye with a high affinity for serum albumin, can bind to the plasma protein albumin to form a 69-kDa tracer, a molecular-sized protein not normally able to penetrate viable cells and peripheral tissues unless vascular leakage or tissue injuries occur [73]. As a result, Evans blue dye is widely used to measure tissue injuries $[35,42,74-76]$. This is likely the reason that Evans blue has previously only been used in analyses of gut leakage using proximal-distal-ligated intestine samples that were isolated from the sacrificed animal [77]; the leakage levels of dead, not live intestinal tissue were recorded. Accordingly, the best time points for the analysis of other cellular and biochemical parameters such as RNA, protein expression, and the cell death status may not be easily available. We demonstrated that the oral administration of Evans blue is a feasible new method for tracking intestinal leakage in live animals. For the development of potential clinical use, a patient-friendly lower-toxicity version of Evans blue or other GI-nonabsorbable highly sensitive tracking dyes are desired.

In this present study, PPI treatments can rescue stress-induced GI leakage in mice. This suggests that the GI $\mathrm{pH}$ homeostasis is disrupted by acute restraint stress. The proton pump is an $\mathrm{H}^{+} / \mathrm{K}^{+}$ATPase located in the parietal cell responsible for acid secretion into the gastric lumen [78]. PPIs are weak bases that accumulate in the acidic space, inhibiting the proton pump to suppress acid secretion [78]. In normal conditions, the gut epithelium in acid-secreting gastric mucosa exports $\mathrm{HCO}_{3}$ to form a mucus-bicarbonate barrier and maintain a neutral $\mathrm{pH}$ at the apical cell surfaces [79]. In this present study, we found that mouse duodenal tissue becomes more acidic after restraint stress, which is associated with downregulated tight junction expression and increased cell death of gut epithelial cells. This suggests a dysregulation of mucus-bicarbonate barrier function occurs after restraint stress and likely the reason that PPI treatments can rescue the stress-increased permeability of GI. Additionally, ATF3 deficiency exacerbates the GI leakage, suggesting ATF3 is directly or indirectly involved in this stress-induced pathophysiology.

As a stress-induced transcription factor, ATF3 plays critical roles in the regulation of cell survival, metabolism, immunity, and oncogenesis $[12,80]$. Various cellular stress signals, such as endoplasmic reticulum stress, cytokines, chemokines, and bacterial lipopolysaccharide, are associated with ATF3 induction [12]. Although the mechanism remains elusive, the emerging roles of ATF3 in the regulation of GI homeostasis has been revealed. For example, ATF3 is critical in the regulation of intestinal regeneration [16], intestinal immunity $[13,15]$, and maintaining healthy intestinal microbiota [14]. The role of ATF3 in stress ulcers, however, remains elusive.

This report demonstrates the pathogenic alternations of an acute stress ulcer in a mouse model. ATF3 deficiency greatly exacerbates stress-induced GI damages, suggesting a protective role of ATF3 toward the stress ulcer. The literature revealed that long-term chronic stress can lead to dysbiosis and GI tract dysfunction $[81,82]$ and may further 
exacerbate neurodegenerative and psychological diseases [83,84]. In experimental colitis, ATF3 modulated the gut epithelial barrier functions and protected against inflammationassociated injuries in mice [85]. However, the role of ATF3 in GI cellular stress and injury in acute stress ulcers is less discussed. Similar to the gut dysbiosis observed in inflammatory GI diseases [86,87], gut microbiota become proinflammatory after long-term restraint stress $[24,88]$. The mechanism of pathophysiological changes at the early phase of stressinduced GI injuries is theoretically crucial for the development of therapeutic approaches against these GI idiopathic inflammatory diseases, in which ATF3 likely plays a role in the maintenance of homeostasis.

In this present mouse model, restraint stress induced ATF3 expression in intestinal epithelial cells of mice. ATF3 deficiency exacerbated the stress-induced GI permeability, which is associated with a disrupted expression of epithelial tight junction. In general, tight junction gene expression plays a protective role in the GI system, while tight junction disruption indicates GI injuries [89-91]. This suggests a protective role of ATF3 in the rescue of stress-induced damage. The literature has reported a protective role of ATF3 on wide-spectrum stress signal-induced cell deaths in numerous cell types. For example, in the vascular system, ATF3 increases the survival rates of vascular smooth muscle cells [92] and protects endothelial cells from tumor necrosis factor $\alpha$-induced cell death [93]. In the neuronal system, ATF3 plays a pro-survival role in ganglion cells and neurons [94]. Consistently, ATF3 protects against doxorubicin-induced apoptosis in cardiac myocytes [95] and stress-induced cell death in renal cells, $\beta$-cells [96], and keloid fibroblasts [97]. The collective evidence suggests that ATF3 plays a protective role in cell-stressed conditions. Therefore, observing the GI epithelial cell protective effects of ATF3 in stress ulcers is reasonable. It is noteworthy that ATF3 also plays vital roles in the nervous system [94]. Consequently, ATF3 may also be involved in the regulation of GI permeability at the "brain" side of the gut-brain axis. The contribution of neuronal ATF3 regulation to GI leakage is worth further investigation.

\section{Conclusions}

Using this new Evans blue-restraint stress mouse model, we determined that the dysregulation of tight junction expression and apoptotic epithelial cell death is involved in stress-induced ulcer-like damages. An ATF3 deficiency exacerbates stress-induced GI leakages, which are associated with the abnormal regulation of epithelial tight junction expressions. These results suggest that, as a native cellular protective pathway in the GI system, ATF3 could be a molecular target for managing psychological stress-induced GI tract diseases. Since long-term stress can lead to GI dysbiosis and inflammatory diseases, these findings could be useful for the development of therapeutic approaches against acute stress ulcers and stress-associated chronic inflammation.

Supplementary Materials: The following are available online at https:/ /www.mdpi.com/article/10 .3390/cells10123530/s1: Figure S1: Stress-induced GI abnormalities. Table S1: List of primers used in this report.

Author Contributions: Conceptualization, H.-H.C.; methodology, D.-J.C.; investigation, S.P., B.S., H.-J.C., S.-C.H., T.-S.L. and D.-S.S.; resources, C.-F.C.; and writing, H.-H.C. All authors have read and agreed to the published version of the manuscript.

Funding: This work was supported by the Ministry of Science and Technology, Taiwan (107-2311-B320-002-MY3) and Tzu-Chi Medical Foundation (TCMMP108, TCMMP111, and TCAS-108).

Institutional Review Board Statement: This study was conducted according to the guidelines of the Declaration of Helsinki and approved by the Animal Care and Use Committee of Tzu-Chi University (approval ID: 110024 on 24 May 2021).

Informed Consent Statement: Not applicable.

Data Availability Statement: The data presented in this study are available in the article and the supplementary material. 
Acknowledgments: The authors are grateful for the support from the research team of Core Facility Center, Tzu Chi University for their help with the flow cytometry and confocal microscopy analyses. The authors thank the technical support from Ya-Hsien Chou at the Confocal Imaging Core of National Tsing Hua University (sponsored by MOST 110-2731-M-007-001). The authors also appreciate Jen-Hung Wang, Department of Medical Research, Tzu Chi General Hospital for his help with the statistical analyses.

Conflicts of Interest: The authors declare no conflict of interest. The funders had no role in the design of the study; in the collection, analyses, or interpretation of the data; in the writing of the manuscript; or in the decision to publish the results.

\section{References}

1. Sapolsky, R.M. Why Zebras Don't Get Ulcers, 3rd ed.; W. H. Freeman: New York, NY, USA, 2004.

2. Oligschlaeger, Y.; Yadati, T.; Houben, T.; Condello Olivan, C.M.; Shiri-Sverdlov, R. Inflammatory Bowel Disease: A Stressed "Gut/Feeling". Cells 2019, 8, 659. [CrossRef] [PubMed]

3. Rao, M.; Gershon, M.D. The bowel and beyond: The enteric nervous system in neurological disorders. Nat. Rev. Gastroenterol. Hepatol. 2016, 13, 517-528. [CrossRef] [PubMed]

4. Disease, G.B.D.; Injury, I.; Prevalence, C. Global, regional, and national incidence, prevalence, and years lived with disability for 354 diseases and injuries for 195 countries and territories, 1990-2017: A systematic analysis for the Global Burden of Disease Study 2017. Lancet 2018, 392, 1789-1858. [CrossRef]

5. Karling, P.; Maripuu, M.; Wikgren, M.; Adolfsson, R.; Norrback, K.F. Association between gastrointestinal symptoms and affectivity in patients with bipolar disorder. World J. Gastroenterol. 2016, 22, 8540-8548. [CrossRef]

6. Severance, E.G.; Prandovszky, E.; Castiglione, J.; Yolken, R.H. Gastroenterology issues in schizophrenia: Why the gut matters. Curr. Psychiatry Rep. 2015, 17, 27. [CrossRef] [PubMed]

7. Zhang, B.; Wang, H.E.; Bai, Y.M.; Tsai, S.J.; Su, T.P.; Chen, T.J.; Wang, Y.P.; Chen, M.H. Inflammatory bowel disease is associated with higher dementia risk: A nationwide longitudinal study. Gut 2021, 70, 85-91. [CrossRef]

8. Alkasir, R.; Li, J.; Li, X.; Jin, M.; Zhu, B. Human gut microbiota: The links with dementia development. Protein Cell 2017, 8, 90-102. [CrossRef] [PubMed]

9. Wasilewska, J.; Klukowski, M. Gastrointestinal symptoms and autism spectrum disorder: Links and risks-A possible new overlap syndrome. Pediatric Health Med. Ther. 2015, 6, 153-166. [CrossRef] [PubMed]

10. Long-Smith, C.; O’Riordan, K.J.; Clarke, G.; Stanton, C.; Dinan, T.G.; Cryan, J.F. Microbiota-Gut-Brain Axis: New Therapeutic Opportunities. Annu. Rev. Pharmacol. Toxicol. 2020, 60, 477-502. [CrossRef]

11. Cryan, J.F.; O’Riordan, K.J.; Cowan, C.S.M.; Sandhu, K.V.; Bastiaanssen, T.F.S.; Boehme, M.; Codagnone, M.G.; Cussotto, S.; Fulling, C.; Golubeva, A.V.; et al. The Microbiota-Gut-Brain Axis. Physiol. Rev. 2019, 99, 1877-2013. [CrossRef] [PubMed]

12. Ku, H.C.; Cheng, C.F. Master Regulator Activating Transcription Factor 3 (ATF3) in Metabolic Homeostasis and Cancer. Front. Endocrinol. 2020, 11, 556. [CrossRef]

13. Glal, D.; Sudhakar, J.N.; Lu, H.H.; Liu, M.C.; Chiang, H.Y.; Liu, Y.C.; Cheng, C.F.; Shui, J.W. ATF3 Sustains IL-22-Induced STAT3 Phosphorylation to Maintain Mucosal Immunity Through Inhibiting Phosphatases. Front. Immunol. 2018, 9, 2522. [CrossRef]

14. Cao, Y.; Wang, X.; Yang, Q.; Deng, H.; Liu, Y.; Zhou, P.; Xu, H.; Chen, D.; Feng, D.; Zhang, H.; et al. Critical Role of Intestinal Microbiota in ATF3-Mediated Gut Immune Homeostasis. J. Immunol. 2020, 205, 842-852. [CrossRef] [PubMed]

15. Cao, Y.; Yang, Q.; Deng, H.; Tang, J.; Hu, J.; Liu, H.; Zhi, M.; Ye, L.; Zou, B.; Liu, Y.; et al. Transcriptional factor ATF3 protects against colitis by regulating follicular helper T cells in Peyer's patches. Proc. Natl. Acad. Sci. USA 2019, 116, 6286-6291. [CrossRef]

16. Zhou, J.; Edgar, B.A.; Boutros, M. ATF3 acts as a rheostat to control JNK signalling during intestinal regeneration. Nat. Commun. 2017, 8, 14289. [CrossRef]

17. Campos, A.C.; Fogaca, M.V.; Aguiar, D.C.; Guimaraes, F.S. Animal models of anxiety disorders and stress. Braz. J. Psychiatry 2013, 35 (Suppl. 2), S101-S111. [CrossRef] [PubMed]

18. Pare, W.P.; Glavin, G.B. Restraint stress in biomedical research: A review. Neurosci. Biobehav. Rev. 1986, 10, 339-370. [CrossRef]

19. Glavin, G.B.; Pare, W.P.; Sandbak, T.; Bakke, H.K.; Murison, R. Restraint stress in biomedical research: An update. Neurosci. Biobehav. Rev. 1994, 18, 223-249. [CrossRef]

20. Santha, P.; Veszelka, S.; Hoyk, Z.; Meszaros, M.; Walter, F.R.; Toth, A.E.; Kiss, L.; Kincses, A.; Olah, Z.; Seprenyi, G.; et al. Restraint Stress-Induced Morphological Changes at the Blood-Brain Barrier in Adult Rats. Front. Mol. Neurosci. 2015, 8, 88. [CrossRef]

21. Zhang, Q.; Wang, X.; Bai, X.; Xie, Y.; Zhang, T.; Bo, S.; Chen, X. Resveratrol reversed chronic restraint stress-induced impaired cognitive function in rats. Mol. Med. Rep. 2017, 16, 2095-2100. [CrossRef]

22. Shoji, H.; Miyakawa, T. Differential effects of stress exposure via two types of restraint apparatuses on behavior and plasma corticosterone level in inbred male BALB/cAJcl mice. Neuropsychopharmacol. Rep. 2020, 40, 73-84. [CrossRef]

23. Dodiya, H.B.; Forsyth, C.B.; Voigt, R.M.; Engen, P.A.; Patel, J.; Shaikh, M.; Green, S.J.; Naqib, A.; Roy, A.; Kordower, J.H.; et al. Chronic stress-induced gut dysfunction exacerbates Parkinson's disease phenotype and pathology in a rotenone-induced mouse model of Parkinson's disease. Neurobiol. Dis. 2020, 135, 104352. [CrossRef] 
24. Gao, X.; Cao, Q.; Cheng, Y.; Zhao, D.; Wang, Z.; Yang, H.; Wu, Q.; You, L.; Wang, Y.; Lin, Y.; et al. Chronic stress promotes colitis by disturbing the gut microbiota and triggering immune system response. Proc. Natl. Acad. Sci. USA 2018, 115, E2960-E2969. [CrossRef] [PubMed]

25. Siopi, E.; Chevalier, G.; Katsimpardi, L.; Saha, S.; Bigot, M.; Moigneu, C.; Eberl, G.; Lledo, P.M. Changes in Gut Microbiota by Chronic Stress Impair the Efficacy of Fluoxetine. Cell Rep. 2020, 30, 3682-3690.e3686. [CrossRef]

26. Deng, Y.; Zhou, M.; Wang, J.; Yao, J.; Yu, J.; Liu, W.; Wu, L.; Wang, J.; Gao, R. Involvement of the microbiota-gut-brain axis in chronic restraint stress: Disturbances of the kynurenine metabolic pathway in both the gut and brain. Gut Microbes 2021, 13, 1869501. [CrossRef] [PubMed]

27. Carabotti, M.; Scirocco, A.; Maselli, M.A.; Severi, C. The gut-brain axis: Interactions between enteric microbiota, central and enteric nervous systems. Ann. Gastroenterol. 2015, 28, 203-209.

28. Galipeau, H.J.; Verdu, E.F. The complex task of measuring intestinal permeability in basic and clinical science. Neurogastroenterol. Motil. 2016, 28, 957-965. [CrossRef]

29. Delvaux, M.; Escourrou, J. Endoscopy in peptic ulcer disease: Diagnosis, prognosis and management. Endoscopy 1992, 24, 41-44. [CrossRef]

30. Dunlap, J.J.; Patterson, S. Peptic Ulcer Disease. Gastroenterol. Nurs. 2019, 42, 451-454. [CrossRef] [PubMed]

31. Ho, Y.Y.; Sun, D.S.; Chang, H.H. Silver Nanoparticles Protect Skin from Ultraviolet B-Induced Damage in Mice. Int. J. Mol. Sci 2020, 21, 7082. [CrossRef] [PubMed]

32. Tsai, C.L.; Sun, D.S.; Su, M.T.; Lien, T.S.; Chen, Y.H.; Lin, C.Y.; Huang, C.H.; King, C.C.; Li, C.R.; Chen, T.H.; et al. Suppressed humoral immunity is associated with dengue nonstructural protein NS1-elicited anti-death receptor antibody fractions in mice. Sci. Rep. 2020, 10, 6294. [CrossRef]

33. Lin, Y.Y.; Hu, C.T.; Sun, D.S.; Lien, T.S.; Chang, H.H. Thioacetamide-induced liver damage and thrombocytopenia is associated with induction of antiplatelet autoantibody in mice. Sci. Rep. 2019, 9, 17497. [CrossRef]

34. Perevedentseva, E.; Krivokharchenko, A.; Karmenyan, A.V.; Chang, H.H.; Cheng, C.L. Raman spectroscopy on live mouse early embryo while it continues to develop into blastocyst in vitro. Sci. Rep. 2019, 9, 6636. [CrossRef] [PubMed]

35. Chan, H.; Huang, H.S.; Sun, D.S.; Lee, C.J.; Lien, T.S.; Chang, H.H. TRPM8 and RAAS-mediated hypertension is critical for cold-induced immunosuppression in mice. Oncotarget 2018, 9, 12781-12795. [CrossRef]

36. Huang, C.Y.; Yu, W.S.; Liu, G.C.; Hung, S.C.; Chang, J.H.; Chang, J.C.; Cheng, C.L.; Sun, D.S.; Lin, M.D.; Lin, W.Y.; et al. Opportunistic gill infection is associated with $\mathrm{TiO}_{2}$ nanoparticle-induced mortality in zebrafish. PLoS ONE 2021, 16, e0247859. [CrossRef] [PubMed]

37. Hartman, M.G.; Lu, D.; Kim, M.L.; Kociba, G.G.G.J.; Shukri, T.; Buteau, J.; Wang, X.; Frankel, W.L.; Guttridge, D.; Prentki, M.; et al. Role for activating transcription factor 3 in stress-induced beta-cell apoptosis. Mol. Cell Biol. 2004, 24, 5721-5732. [CrossRef] [PubMed]

38. Cheng, C.F.; Ku, H.C.; Cheng, J.J.; Chao, S.W.; Li, H.F.; Lai, P.F.; Chang, C.C.; Don, M.J.; Chen, H.H.; Lin, H. Adipocyte browning and resistance to obesity in mice is induced by expression of ATF3. Commun. Biol. 2019, 2, 389. [CrossRef] [PubMed]

39. Zimprich, A.; Garrett, L.; Deussing, J.M.; Wotjak, C.T.; Fuchs, H.; Gailus-Durner, V.; de Angelis, M.H.; Wurst, W.; Holter, S.M. A robust and reliable non-invasive test for stress responsivity in mice. Front. Behav. Neurosci. 2014, 8, 125. [CrossRef] [PubMed]

40. Chu, X.; Zhou, Y.; Hu, Z.; Lou, J.; Song, W.; Li, J.; Liang, X.; Chen, C.; Wang, S.; Yang, B.; et al. 24-hour-restraint stress induces long-term depressive-like phenotypes in mice. Sci. Rep. 2016, 6, 32935. [CrossRef]

41. Lien, T.S.; Sun, D.S.; Hung, S.C.; Wu, W.S.; Chang, H.H. Dengue Virus Envelope Protein Domain III Induces Nlrp3 InflammasomeDependent NETosis-Mediated Inflammation in Mice. Front. Immunol. 2021, 12, 618577. [CrossRef]

42. Lien, T.S.; Sun, D.S.; Wu, C.Y.; Chang, H.H. Exposure to Dengue Envelope Protein Domain III Induces Nlrp3 InflammasomeDependent Endothelial Dysfunction and Hemorrhage in Mice. Front. Immunol 2021, 12, 617251. [CrossRef]

43. Lien, T.S.; Chan, H.; Sun, D.S.; Wu, J.C.; Lin, Y.Y.; Lin, G.L.; Chang, H.H. Exposure of Platelets to Dengue Virus and Envelope Protein Domain III Induces Nlrp3 Inflammasome-Dependent Platelet Cell Death and Thrombocytopenia in Mice. Front. Immunol. 2021, 12, 616394. [CrossRef] [PubMed]

44. Wilcz-Villega, E.M.; McClean, S.; O'Sullivan, M.A. Mast cell tryptase reduces junctional adhesion molecule-A (JAM-A) expression in intestinal epithelial cells: Implications for the mechanisms of barrier dysfunction in irritable bowel syndrome. Am. J. Gastroenterol. 2013, 108, 1140-1151. [CrossRef]

45. Zhao, X.; Zeng, H.; Lei, L.; Tong, X.; Yang, L.; Yang, Y.; Li, S.; Zhou, Y.; Luo, L.; Huang, J.; et al. Tight junctions and their regulation by non-coding RNAs. Int. J. Biol. Sci. 2021, 17, 712-727. [CrossRef]

46. Zeisel, M.B.; Dhawan, P.; Baumert, T.F. Tight junction proteins in gastrointestinal and liver disease. Gut 2019, 68, 547-561. [CrossRef] [PubMed]

47. Luissint, A.C.; Nusrat, A.; Parkos, C.A. JAM-related proteins in mucosal homeostasis and inflammation. Semin. Immunopathol. 2014, 36, 211-226. [CrossRef]

48. Ouchi, T.; Morimura, S.; Dow, L.E.; Miyoshi, H.; Udey, M.C. EpCAM (CD326) Regulates Intestinal Epithelial Integrity and Stem Cells via Rho-Associated Kinase. Cells 2021, 10, 256. [CrossRef]

49. Balfe, A.; Lennon, G.; Lavelle, A.; Docherty, N.G.; Coffey, J.C.; Sheahan, K.; Winter, D.C.; O'Connell, P.R. Isolation and gene expression profiling of intestinal epithelial cells: Crypt isolation by calcium chelation from in vivo samples. Clin. Exp. Gastroenterol. 2018, 11, 29-37. [CrossRef] [PubMed] 
50. Wang, T.F.; Lin, G.L.; Chu, S.C.; Chen, C.C.; Liou, Y.S.; Chang, H.H.; Sun, D.S. AQP0 is a novel surface marker for deciphering abnormal erythropoiesis. Stem. Cell Res. Ther. 2021, 12, 274. [CrossRef]

51. Mandal, J.P.; Shiue, C.N.; Chen, Y.C.; Lee, M.C.; Yang, H.H.; Chang, H.H.; Hu, C.T.; Liao, P.C.; Hui, L.C.; You, R.I.; et al. PKCdelta mediates mitochondrial ROS generation and oxidation of HSP60 to relieve RKIP inhibition on MAPK pathway for HCC progression. Free Radic. Biol. Med. 2021, 163, 69-87. [CrossRef]

52. Chen, T.L.; Chiang, Y.W.; Lin, G.L.; Chang, H.H.; Lien, T.S.; Sheh, M.H.; Sun, D.S. Different effects of granulocyte colonystimulating factor and erythropoietin on erythropoiesis. Stem. Cell. Res. Ther. 2018, 9, 119. [CrossRef] [PubMed]

53. Moolenbeek, C.; Ruitenberg, E.J. The "Swiss roll": A simple technique for histological studies of the rodent intestine. Lab. Anim. 1981, 15, 57-59. [CrossRef]

54. Bialkowska, A.B.; Ghaleb, A.M.; Nandan, M.O.; Yang, V.W. Improved Swiss-rolling Technique for Intestinal Tissue Preparation for Immunohistochemical and Immunofluorescent Analyses. J. Vis. Exp. 2016, 2016, 54161. [CrossRef]

55. Naud, S. Writing a Rationale Justifying Animal Numbers. In Statistical Justification of Animal Numbers Used in Research and Teaching; COM Biostatistics Unit, The University of Vermont: Burlington, VT, USA, 2020; Available online: https://www.uvm.edu/sites/ default/files/Research-Protections-Office/Statistical_Justification_of_Animal_Numbers_Used_in_Research_and_Training.pdf (accessed on 2 November 2021).

56. Festing, M.F.W.; Overend, P.; Das, R.G.; Borja, C.M.; Berdoy, M. Reducing the Use of Animals in Research through Better Experimental Design. In The Design of Animal Experiments; Royal Society of Medicine Press Limited: London, UK, 2002.

57. Charan, J.; Kantharia, N.D. How to calculate sample size in animal studies? J. Pharmacol. Pharmacother. 2013, 4, 303-306. [CrossRef] [PubMed]

58. Faul, F.; Erdfelder, E.; Lang, A.G.; Buchner, A. G*Power 3: A flexible statistical power analysis program for the social, behavioral, and biomedical sciences. Behav. Res. Methods 2007, 39, 175-191. [CrossRef] [PubMed]

59. Mateer, S.W.; Cardona, J.; Marks, E.; Goggin, B.J.; Hua, S.; Keely, S. Ex Vivo Intestinal Sacs to Assess Mucosal Permeability in Models of Gastrointestinal Disease. J. Vis. Exp. 2016, 2016, e53250. [CrossRef] [PubMed]

60. Nishiyama, K.; Sugiyama, M.; Mukai, T. Adhesion Properties of Lactic Acid Bacteria on Intestinal Mucin. Microorganisms 2016, 4, 34. [CrossRef] [PubMed]

61. Milosavljevic, T.; Kostic-Milosavljevic, M.; Jovanovic, I.; Krstic, M. Complications of peptic ulcer disease. Dig. Dis 2011, 29, 491-493. [CrossRef]

62. Kamada, T.; Satoh, K.; Itoh, T.; Ito, M.; Iwamoto, J.; Okimoto, T.; Kanno, T.; Sugimoto, M.; Chiba, T.; Nomura, S.; et al. Evidence-based clinical practice guidelines for peptic ulcer disease 2020. J. Gastroenterol. 2021, 56, 303-322. [CrossRef] [PubMed]

63. Reshetnyak, V.I.; Burmistrov, A.I.; Maev, I.V. Helicobacter pylori: Commensal, symbiont or pathogen? World J. Gastroenterol. 2021, 27, 545-560. [CrossRef]

64. Levenstein, S.; Rosenstock, S.; Jacobsen, R.K.; Jorgensen, T. Psychological stress increases risk for peptic ulcer, regardless of Helicobacter pylori infection or use of nonsteroidal anti-inflammatory drugs. Clin. Gastroenterol. Hepatol. 2015, 13, 498-506.e491. [CrossRef]

65. Lee, Y.B.; Yu, J.; Choi, H.H.; Jeon, B.S.; Kim, H.K.; Kim, S.W.; Kim, S.S.; Park, Y.G.; Chae, H.S. The association between peptic ulcer diseases and mental health problems: A population-based study: A STROBE compliant article. Medicine 2017, 96, e7828. [CrossRef] [PubMed]

66. Melinder, C.; Udumyan, R.; Hiyoshi, A.; Brummer, R.J.; Montgomery, S. Decreased stress resilience in young men significantly increases the risk of subsequent peptic ulcer disease-A prospective study of 233093 men in Sweden. Aliment. Pharmacol. Ther. 2015, 41, 1005-1015. [CrossRef] [PubMed]

67. Fossmark, R.; Martinsen, T.C.; Waldum, H.L. Adverse Effects of Proton Pump Inhibitors-Evidence and Plausibility. Int. J. Mol. Sci. 2019, 20, 5203. [CrossRef]

68. Bjorkman, D.J. Psychological Stress and Peptic Ulcer. N. Engl. J. Med. J. Watch. 2014, $2014,1$.

69. Lange, S.; Delbro, D.S.; Jennische, E. Evans blue permeation of intestinal mucosa in the rat. Scand. J. Gastroenterol. 1994, $29,38-46$. [CrossRef] [PubMed]

70. Wick, M.J.; Harral, J.W.; Loomis, Z.L.; Dempsey, E.C. An Optimized Evans Blue Protocol to Assess Vascular Leak in the Mouse. J. Vis. Exp. 2018, 139, e57037. [CrossRef]

71. Tolstanova, G.; Deng, X.; French, S.W.; Lungo, W.; Paunovic, B.; Khomenko, T.; Ahluwalia, A.; Kaplan, T.; Dacosta-Iyer, M.; Tarnawski, A.; et al. Early endothelial damage and increased colonic vascular permeability in the development of experimental ulcerative colitis in rats and mice. Lab. Investig. 2012, 92, 9-21. [CrossRef]

72. Evans, H.M.; Schulemann, W. The Action of Vital Stains Belonging to the Benzidine Group. Science 1914, 39, 443-454. [CrossRef]

73. Yao, L.; Xue, X.; Yu, P.; Ni, Y.; Chen, F. Evans Blue Dye: A Revisit of Its Applications in Biomedicine. Contrast Media Mol. Imaging 2018, 2018, 7628037. [CrossRef]

74. Sun, D.S.; Chang, Y.C.; Lien, T.S.; King, C.C.; Shih, Y.L.; Huang, H.S.; Wang, T.Y.; Li, C.R.; Lee, C.C.; Hsu, P.N.; et al. Endothelial Cell Sensitization by Death Receptor Fractions of an Anti-Dengue Nonstructural Protein 1 Antibody Induced Plasma Leakage, Coagulopathy, and Mortality in Mice. J. Immunol. 2015, 195, 2743-2753. [CrossRef]

75. Sun, D.S.; Lee, P.C.; Kau, J.H.; Shih, Y.L.; Huang, H.H.; Li, C.R.; Lee, C.C.; Wu, Y.P.; Chen, K.C.; Chang, H.H. Acquired coagulant factor VIII deficiency induced by Bacillus anthracis lethal toxin in mice. Virulence 2015, 6, 466-475. [CrossRef] [PubMed] 
76. Sun, D.S.; Chang, Y.W.; Kau, J.H.; Huang, H.H.; Ho, P.H.; Tzeng, Y.J.; Chang, H.H. Soluble P-selectin rescues mice from anthrax lethal toxin-induced mortality through PSGL-1 pathway-mediated correction of hemostasis. Virulence 2017, 8, 1216-1228. [CrossRef] [PubMed]

77. Mei, Q.; Diao, L.; Xu, J.M.; Liu, X.C.; Jin, J. A protective effect of melatonin on intestinal permeability is induced by diclofenac via regulation of mitochondrial function in mice. Acta Pharmacol. Sin. 2011, 32, 495-502. [CrossRef] [PubMed]

78. Helgadottir, H.; Bjornsson, E.S. Problems Associated with Deprescribing of Proton Pump Inhibitors. Int. J. Mol. Sci. 2019, 20, 5469. [CrossRef]

79. Laine, L.; Takeuchi, K.; Tarnawski, A. Gastric mucosal defense and cytoprotection: Bench to bedside. Gastroenterology 2008, 135, 41-60. [CrossRef] [PubMed]

80. Sun, D.S.; Chang, H.H. Emerging role of the itaconate-mediated rescue of cellular metabolic stress. Tzu Chi Med. J. 2021, 33, 1-5. [CrossRef]

81. Sun, Y.; Li, L.; Xie, R.; Wang, B.; Jiang, K.; Cao, H. Stress Triggers Flare of Inflammatory Bowel Disease in Children and Adults. Front. Pediatrics 2019, 7, 432. [CrossRef]

82. Rengarajan, S.; Knoop, K.A.; Rengarajan, A.; Chai, J.N.; Grajales-Reyes, J.G.; Samineni, V.K.; Russler-Germain, E.V.; Ranganathan, P.; Fasano, A.; Sayuk, G.S.; et al. A Potential Role for Stress-Induced Microbial Alterations in IgA-Associated Irritable Bowel Syndrome with Diarrhea. Cell Rep. Med. 2020, 1, 100124. [CrossRef]

83. Gubert, C.; Kong, G.; Renoir, T.; Hannan, A.J. Exercise, diet and stress as modulators of gut microbiota: Implications for neurodegenerative diseases. Neurobiol. Dis. 2020, 134, 104621. [CrossRef]

84. Madison, A.; Kiecolt-Glaser, J.K. Stress, depression, diet, and the gut microbiota: Human-bacteria interactions at the core of psychoneuroimmunology and nutrition. Curr. Opin. Behav. Sci. 2019, 28, 105-110. [CrossRef]

85. Sheng, N.; Ma, Z.; Zhou, Y.; Xu, J.; Gao, Y.; Fu, X.Y. Cholesterol 25-hydroxylase protects against experimental colitis in mice by modulating epithelial gut barrier function. Sci. Rep. 2020, 10, 14246. [CrossRef] [PubMed]

86. Levy, M.; Kolodziejczyk, A.A.; Thaiss, C.A.; Elinav, E. Dysbiosis and the immune system. Nat. Rev. Immunol. 2017, 17, 219-232. [CrossRef] [PubMed]

87. Kaur, N.; Chen, C.C.; Luther, J.; Kao, J.Y. Intestinal dysbiosis in inflammatory bowel disease. Gut Microbes 2011, 2, 211-216. [CrossRef]

88. Israeli, E.; Hershcovici, T.; Berenshtein, E.; Zannineli, G.; Wengrower, D.; Weiss, O.; Chevion, M.; Goldin, E. The effect of restraint stress on the normal colon and on intestinal inflammation in a model of experimental colitis. Dig. Dis. Sci. 2008, 53, 88-94. [CrossRef] [PubMed]

89. Liu, C.; Duan, Z.; Guan, Y.; Wu, H.; Hu, K.; Gao, X.; Yuan, F.; Jiang, Z.; Fan, Y.; He, B.; et al. Increased expression of tight junction protein occludin is associated with the protective effect of mosapride against aspirin-induced gastric injury. Exp. Ther. Med. 2018, 15, 1626-1632. [CrossRef]

90. Slifer, Z.M.; Blikslager, A.T. The Integral Role of Tight Junction Proteins in the Repair of Injured Intestinal Epithelium. Int. J. Mol. Sci. 2020, 21, 972. [CrossRef]

91. Caron, T.J.; Scott, K.E.; Fox, J.G.; Hagen, S.J. Tight junction disruption: Helicobacter pylori and dysregulation of the gastric mucosal barrier. World J. Gastroenterol. 2015, 21, 11411-11427. [CrossRef] [PubMed]

92. Lv, D.; Meng, D.; Zou, F.F.; Fan, L.; Zhang, P.; Yu, Y.; Fang, J. Activating transcription factor 3 regulates survivability and migration of vascular smooth muscle cells. IUBMB Life 2011, 63, 62-69. [CrossRef] [PubMed]

93. Kawauchi, J.; Zhang, C.; Nobori, K.; Hashimoto, Y.; Adachi, M.T.; Noda, A.; Sunamori, M.; Kitajima, S. Transcriptional repressor activating transcription factor 3 protects human umbilical vein endothelial cells from tumor necrosis factor-alpha-induced apoptosis through down-regulation of p53 transcription. J. Biol. Chem. 2002, 277, 39025-39034. [CrossRef] [PubMed]

94. Hunt, D.; Raivich, G.; Anderson, P.N. Activating transcription factor 3 and the nervous system. Front. Mol. Neurosci. 2012, 5, 7. [CrossRef] [PubMed]

95. Nobori, K.; Ito, H.; Tamamori-Adachi, M.; Adachi, S.; Ono, Y.; Kawauchi, J.; Kitajima, S.; Marumo, F.; Isobe, M. ATF3 inhibits doxorubicin-induced apoptosis in cardiac myocytes: A novel cardioprotective role of ATF3. J. Mol. Cell. Cardiol. 2002, 34, 1387-1397. [CrossRef] [PubMed]

96. Yoshida, T.; Sugiura, H.; Mitobe, M.; Tsuchiya, K.; Shirota, S.; Nishimura, S.; Shiohira, S.; Ito, H.; Nobori, K.; Gullans, S.R.; et al. ATF3 protects against renal ischemia-reperfusion injury. J. Am. Soc. Nephrol. 2008, 19, 217-224. [CrossRef] [PubMed]

97. Wang, X.M.; Liu, X.M.; Wang, Y.; Chen, Z.Y. Activating transcription factor 3 (ATF3) regulates cell growth, apoptosis, invasion and collagen synthesis in keloid fibroblast through transforming growth factor beta (TGF-beta)/SMAD signaling pathway. Bioengineered 2021, 12, 117-126. [CrossRef] [PubMed] 